\title{
An interpersonal sketch of the biblical Hebrew clause
}

\author{
Eric T. Racher
}

Correspondence:

eric.racher@gmail.com

Independent Researcher, Riga,

Latvia

\begin{abstract}
The aim of the present paper is to describe the Biblical Hebrew clause as a locus of interpersonal meanings from a systemic functional perspective. Although systemic functional linguistics has been applied to the description of an increasing number of languages in recent years, systemic functional accounts of Semitic languages remain limited in number. This paper brings together work on the English MOOD system and systemic functional typological literature, applying them to the development of a partial description of one aspect of the lexicogrammar of Biblical Hebrew. In this paper the realization of interpersonal meanings is explored through analysis of dialogic interaction in the Biblical text, showing how the MOOD system realizes speech functions and outlining a preliminary system network for Biblical Hebrew MOOD, with particular emphasis on the systemic potential of MOOD TYPE. The mood structure is also analyzed from below, and the elements salient to the negotiation of meanings in interaction are presented individually and their relevance to the realization of interpersonal meanings is explored.
\end{abstract}

Keywords: Mood, Interpersonal metafunction, Biblical Hebrew, SFL, Lexicogrammar

\section{Introduction}

Although functional approaches to linguistic analysis have become more widespread in the study of Ancient Hebrew in recent decades, surprisingly little work has been carried out from the perspective of Systemic Functional Grammar (SFG), in spite of the more widespread representation of other functional schools in the literature (Anstey 2009; van der Merwe 2003). Some scholars reference Halliday in their studies, but do not approach Ancient Hebrew from a systemic functional perspective ((Andersen 1986); Levinsohn and Stephen 1990; (Waltke \& O'Connor 1990); Floor, 2004; (Brettler 2010; Li 2006; Polak 2006)); others have taken SFG as their framework for the analysis of a particular aspect of or construction in Hebrew texts (Madasu 2015; Toffelmire 2014), yet more complete analyses and descriptions of Hebrew lexicogrammar are lacking in the literature. Two recent exceptions to this tendency are Bandstra (Bandstra 2008) and Tatu (Tatu 2008). ${ }^{1}$ The former is a handbook to the first eleven chapters of Genesis, written for intermediate and advanced students of Biblical Hebrew, and consists of a detailed systemic functional analysis of the text. The latter is a comparative study of verbal sequences in Hebrew and Ugaritic poetry, which approaches the topic from a systemic functional perspective and includes a chapter in which the author sketches

(C) The Author(s). 2017 Open Access This article is distributed under the terms of the Creative Commons Attribution 4.0 International License (http://creativecommons.org/licenses/by/4.0/), which permits unrestricted use, distribution, and reproduction in any medium, provided you give appropriate credit to the original author(s) and the source, provide a link to the Creative Commons license, and indicate if changes were made. 
an outline of a systemic functional description of Biblical Hebrew. While these are both important forays into the application of Systemic Functional Grammar to Biblical Hebrew, neither account is wholly satisfactory, mainly due to their tendency to adhere too closely to categories established in descriptions of the English language.

The present study explores the Biblical Hebrew clause as a locus of interpersonal meanings from a systemic functional perspective. The first section presents an outline of the history of Biblical Hebrew, in order to provide contextualization for the description which follows. The following section discusses those systems at clause rank associated with interpersonal meanings. This account will be followed by a brief critical appraisal of those in Bandstra (Bandstra 2008) and Tatu (Tatu 2008). Finally, a provisional description of the $\mathrm{MOOD}^{2}$ system in Biblical Hebrew will be outlined, with particular emphasis on the system of MOOD TYPE, and the mood structure of the clause will be analyzed from below, with the elements salient to negotiation in interpersonal interaction explored individually with regard to their roles in the realization of interpersonal meanings.

\section{Biblical Hebrew}

Hebrew is a Semitic language belonging to the Canaanite family of the Northwest Semitic group of languages, together with Aramaic, Amorite, Phoenician, Ugaritic and others. In its ancient form, Hebrew was the language of the Israelite tribes which settled the land known as Canaan and established a kingdom there around the turn of the first millennium BCE, which would eventually split into a northern kingdom (Israel) and a southern kingdom (Judah), each associated with its own regional variety of the language ((Edzard 2011): 480-481; (Steiner 1997): 145; (Rendsburg 2003)). In 722 BCE, the northern kingdom was conquered by the Assyrians, who exiled a substantial portion of the population, and in 597 the Babylonian ruler Nebuchadnezzar II asserted control over Judah, where ten years later he would lay siege to Jerusalem, destroy the Temple of Solomon and exile a substantial portion of the local population to Babylon ((van de Mieroop 2007): 251 and 276). These exiles were eventually allowed to return and rebuild the Temple, and an independent Judean state was established during the Hellenistic period ((Steiner 1997): 145). The Roman empire conquered this independent state, destroyed the Second Temple in $70 \mathrm{CE}$, and, after the Bar-Kokhba revolt of 132-135 CE, dispersed the inhabitants throughout the empire (ibid.). These historical events would have a decisive impact on the history of the language itself.

Historically, Hebrew may be classified into four main periods: Biblical Hebrew (BH), Rabbinic Hebrew, Medieval Hebrew and Modern (Israeli) Hebrew; the earliest attested epigraphic materials in BH date to the tenth century BCE ((Sáenz-Badillos 1993): 43 and 51-52). The language of the Hebrew Bible is mostly of the Judahite variety, and may be further subdivided into three stages: Archaic BH (ca. 1100-1000 BCE), Standard BH (ca. 1000-550 BCE), and late BH (ca. 550-200 BCE) ((Edzard 2011): 481). Outside of the biblical text, there are a number of inscriptions beginning from ca. $1200 \mathrm{BCE}$ to 132-135 CE, the Dead Sea scrolls, and the Samaritan Pentateuch, which provide further linguistic evidence of ancient Hebrew in addition to what may be called, strictu sensu, Biblical Hebrew ((Edzard 2011): 480). The complete text of the Hebrew Bible has been 
preserved in the Tiberian vocalization tradition, which was fixed by scholars between the $7^{\text {th }}$ and $9^{\text {th }}$ centuries CE ((Edzard 2011): 481). It is this text which constitutes the corpus analyzed in the present paper.

\section{Interpersonal meanings}

In this section, the notion of the interpersonal metafunction as developed in Systemic Functional Linguistics is outlined. The first subsection discusses the contextual variable of tenor and its relation to the semantic system of SPEECH FUNCTION. Following this, the lexicogrammatical system of MOOD is presented, based on the standard description of the English clause found in Halliday and Matthiessen (Halliday \& Matthiessen 2014).

\section{Tenor and speech function}

The present study focuses on the realization of interpersonal meanings at the clause level of language. The interpersonal metafunction is associated with the contextual variable known as tenor, which refers to the nature of the roles (institutional, status, contact and sociometric) of the interactants as well as the values and attitudes (neutral or positively/negatively loaded) that the interactants bring to the domain ((Halliday \& Matthiessen 2014): 32-33). The semantic system associated with these factors of interpersonal communication is referred to as SPEECH FUNCTION, which simultaneously realizes the three systems of MOVE, INITIATING ROLE, and COMMODITY. This semantic system creates meanings related to the contextual variable of tenor, and these meanings are realized on the stratum of lexicogrammar by means of the MOOD system. The entry condition to the system of SPEECH FUNCTION is a move in the exchange.

The system of COMMODITY deals with the nature of that which is being exchanged in an interaction: either goods \& services (nonverbal) or information (verbal). INITIATING ROLE, on the other hand, refers to "[t]he most fundamental types of speech role" in any interaction, i.e., giving and demanding (ibid.). These two systems are considered to be essential features lying behind the MOOD systems of all languages ((Matthiessen 2004): 610). The combination of the different terms of these two systems results in four primary speech functions: offer, command, statement, and question, as shown in Table 1, which are, furthermore, "matched by a set of desired responses: accepting an offer, carrying out a command, acknowledging a statement and answering a question" ((Halliday \& Matthiessen 2014): 135).

The final subsystem of SPEECH FUNCTION classifies the type of MOVE utilized in an interaction. Thus, an exchange begins with a move, i.e., one of the participants produces an utterance which is a single semantic unit, a quantum of exchange in the

Table 1 Primary speech functions resulting from intersection of commodity type and initiating role type

\begin{tabular}{lll}
\hline & Information & Goods \& services \\
\hline Give & statement & offer \\
Demand & question & command \\
\hline
\end{tabular}


interaction, and any such utterance may be classified as either an initiating move or a responding move according to its relation to the other moves in the exchange. Although the move is the basic unit of dialogue on the semantic level, and the entry point into the semantic system of SPEECH FUNCTION, this semantic unit is realized on the lexicogrammatical level by a free clause, which is the entry point to the grammatical system network of MOOD. This clause may be a proposition (a statement or a question) or a proposal (an offer or a command); i.e., a proposition has the semantic function of exchanging information, while a proposal has the semantic function of exchanging goods \& services (Halliday and Michael 1995:12; (Halliday \& Matthiessen 2014): 139).

In summary, the interpersonal meaning of the clause hinges on the role the clause plays in an exchange. When two or more people engage in dialogue, they assume certain speech roles and assign other ones to their interlocutors, and each one may initiate exchanges and/or respond in either an expected or discretionary manner to exchanges initiated by others. The two main variables in any exchange are the type of speech role (giving or demanding) and the type of commodity exchanged (information or goods\&-services). These two variables combine together, producing the following four primary speech functions: offer (giving goods-\&-services), command (demanding goods-\&-services), statement (giving information), and question (demanding information). The following section will discuss how these semantic elements are realized in the lexicogrammatical system of MOOD.

\section{Mood}

Unlike the system of SPEECH FUNCTION, which operates on the semantic stratum, the MOOD system is located on the stratum of lexicogrammar, at the level of clause rank. The SPEECH FUNCTION system is "a resource for enacting the roles and relations that make up the tenor aspect of context", while the MOOD system in its turn is "a resource for realizing exchanges in the development of dialogue" ((Teruya et al. 2007): 866). As a consequence, the primary speech functions can be mapped onto the MOOD TYPE choices typically found in the MOOD systems of languages and their various realizations: statements are prototypically realized by means of declarative clauses, questions by means of interrogative clauses, and commands by means of imperative clauses, whereas offers do not generally correspond to a specific choice in the system of MOOD TYPE, but may be realized in various ways (ibid. 867-868). The following account of the English MOOD system is based on the fourth chapter of Halliday and Matthiessen (Halliday \& Matthiessen 2014).

In English, the most distinctive aspect of the grammatical system of MOOD is the Mood element, which is the locus of interpersonal negotiation in the clause, conveying the progression of the interaction and changing when necessary in the process of negotiation. There are two components in the Mood element: the Subject and the Finite operator. The Subject is typically a nominal group, while the Finite is part of the verbal group. The Subject provides "something by reference to which the proposition can be affirmed or denied," that is, "the entity in respect of which the assertion is claimed to have validity" ((Halliday \& Matthiessen 2014): 146). The Finite element limits the clause in relation to the context of the speech event by means of primary tense (which relates 
the clause to the time of speaking) and modality (which refers to the speaker's judgment regarding the likelihood that a proposition is true or regarding the desirability of a proposal). Polarity, or the choice between positive and negative, is also related to the arguability of the Mood element, and is typically realized by the positive and negative forms of the Finite operators in English.

The Mood element "realizes the selection of mood in the clause; and it is also the domain of agreement between Subject and Finite" ((Halliday \& Matthiessen 2014): 142). In the lexicogrammatical expression of MOOD, the imperative is used to demand goods-\&-services (and realizes a command), while the indicative is typically used to exchange information. There are two types of indicative: declarative (which realizes a statement) and interrogative (which realizes a question). In English, the presence or absence of the Mood element realizes distinctions between unmarked imperative and indicative clauses, while differences in the ordering of the elements (as well as the present or absence of a WH- element) realize the distinction between declarative and interrogative clauses. The rest of the clause is referred to as the Residue, and may contain other elements relevant to the system of MOOD - Predicator, Complement and Adjunct - although these are not part of the Mood element itself. Certain other interpersonally salient elements, i.e. Vocatives, are outside of the Mood + Residue structure altogether.

In other languages, however, the distinctions realized in English by means of variations in the order of elements within the Mood element may be realized differently - for example, by means of particles or in the verbal morphology of the Predicator ((Halliday \& Matthiessen 2014): 142 and 170; (Teruya et al. 2007)). Halliday and Matthiessen (Halliday \& Matthiessen 2014) explain that, while it is true that "[c]ertain other languages operate with a similar Mood element consisting of Subject + Finite [in which] the relative sequence of Subject and Finite serves to realize the selection of mood in the clause", this is not the case with all languages, which may use Negotiator particles or tone to accomplish the same things (see the discussion of individual languages in (Caffarel et al. 2004) as well as (Teruya et al. 2007)). For example, in Caffarel's (Caffarel 2006) systemic functional description of French, the most salient part of the clause is called the Negotiator, and consists of three elements (Subject, Finite and Predicator), all of which have equal weight in negotiating interpersonal meanings in the clause, whereas the Remainder includes Complements and Adjuncts, and other elements are outside of this Negotiator + Remainder structure. Minh Duc Thai's (Thai 2004) description of Vietnamese instead places the interpersonal burden of the clause on a clause element referred to as the Negotiatory element, which consists of the Predicator and Negotiator, which is realized by an interpersonal particle. In their Introduction, Caffarel et al. (Caffarel et al. 2004) summarize Halliday's description of the English MOOD system, noting that the patterns described "are specific to the systemic functional description of English". It will be shown below that, while there are similarities in the MOOD systems of Biblical Hebrew and English, there are also very important differences in the way the system is realized.

As mentioned above, the English Residue consists of three elements: Predicator, Complement and circumstantial Adjunct. The Predicator comprises the clause's verbal group minus the Finite operator, and has four main functions: (1) to specify time reference relative to primary tense (secondary tense), (2) to specify other 
aspects or phases (seeming, trying, etc.), (3) to specify voice, and (4) to specify the process. The Complement is typically a nominal group that is said to have "the potential for being given the interpersonally elevated status of modal responsibility", i.e. to be Subject although it is not ((Halliday \& Matthiessen 2014): 153). Differently from the Complement, circumstantial Adjuncts do not have the potential to be the Subject of the clause, because they represent peripheral circumstances in the transitivity structure of the clause.

In addition to the circumstantial Adjunct, there are two types of modal Adjunct associated with the interpersonal metafunction: mood Adjuncts and comment Adjuncts. Mood Adjuncts are located within the Mood element, are closely linked to the Finite, and are associated with modality, temporality and intensity. On the other hand, comment Adjuncts are located outside of the Mood + Residue structure, and as their name suggests, function as "comments on it (propositional) or on the act of exchanging it (speech-functional) ((Halliday \& Matthiessen 2014): 184).

The core systems of modal assessment in English are MODALITY and POLARITY, both of which are highly grammaticalized. The MODALITY system construes a range of possibilities between the positive and negative poles of the POLARITY system. The range of possibilities is different for propositions and proposals. Propositions assert and deny information and are related to degrees of probability and degrees of usuality, which are referred to as modalization. Modalization can be expressed by means of Finite modal operators, modal Adjuncts or both. Proposals, on the other hand, are related to the concept of modulation, and refer to the interpersonal acts of prescribing and proscribing. Modulation includes degrees of obligation for commands and degrees of inclination in offers, and can be expressed by Finite modal operators or by "an expansion of the Predicator through verbal group complexing” ((Halliday \& Matthiessen 2014): 178).

\section{Biblical Hebrew Mood}

This section develops an account of the MOOD system in the Biblical Hebrew clause. It begins by reviewing two recent attempts at applying SFG to the biblical text, and rejecting them as inadequate. This is followed by a discussion of how the basic speech functions are realized in an example of dialogic interaction. The Biblical Hebrew MOOD system is then presented and analyzed, including the individual elements involved in the Mood structure and those systems involved in modal assessment.

Mood in Bandstra (Bandstra 2008) and Tatu (Tatu 2008)

Bandstra (Bandstra 2008) is a handbook for intermediate and advanced students of $\mathrm{BH}$, which provides a detailed systemic functional analysis of the text of Genesis chapters one through eleven, as well as a basic introduction to SFG focused on the three metafunctions in the BH clause. Bandstra generally adheres rather closely to Halliday's account of English Mood, focusing on the importance of the Subject and Finite in the realization of mood structure, and he does not explicitly explain how this differs from English Mood except to note that the Subject is an optional element in the clause. Furthermore, Bandstra (Bandstra 2008) discusses tests for the determination of the Subject which are based on his English translation of the BH clause used as an example, and 
which do not work with the original Hebrew text. These tests appear to be derived from the treatment of the English Subject in Halliday's work ((Halliday \& Matthiessen 2014): 145-148). The term 'Finite' in Bandstra's account seems to refer to a fused Finite/Predicator element, as his exposition does not include the notion of Predicator, and the Process in his Transitivity analysis is associated with the Finite. No realization statements are provided beyond the comments that "a directive clause typically places the Finite first in its clause and has no explicit Subject," and "an interrogative places the question word first in its clause" (ibid. 7).

Tatu (Tatu 2008) utilizes SFG in the analysis of verbal sequences of BH poetry. While the bulk of the text is concerned with the problem, methods and analysis, the author does provide an attempt at outlining the lexicogrammar of $\mathrm{BH}$ prose texts. Tatu begins his description of $\mathrm{BH}$ Mood with an exposition of the basic speech functions, their realizations in different Mood types and the typical order of constituents in the realization of each Mood type in the mood structure. Table 2 below reproduces the system found in Tatu (Tatu 2008).

While the less delicate distinctions in Tatu's system of Mood type are noncontroversial and correspond to the general distinctions recognized in the typological literature, the more delicate distinctions appear to confound Mood type with its realizations and with Process type. Furthermore, although constituent order is a vital aspect of the realization of Mood type in English, the order of constituents is not relevant to the selection of Mood in $\mathrm{BH}$, although a possible exception is discussed below in section Mood type.

Like Bandstra, Tatu analyzes the Mood structure of the BH clause into a Mood element consisting of Subject and Finite, and a Residue element; however, in Tatu's account the Residue consists of Predicator, Complement and Adjunct, which even more closely adheres to Halliday's description of English. The Finite and Predicator are described as a fused element, taking part in both the Mood and the Residue. Tatu also uses a similar English example of the mood tag structure to illustrate the notion of Subject in BH.

Table 2 Constituent order according to mood type ((Tatu 2008): 182-283)

\begin{tabular}{|c|c|}
\hline Mood type & Order of constituents \\
\hline Declarative: finite & Finite/Predicator^Subject \\
\hline Declarative: non-finite: infinitive absolute/construct & Finite/Predicator^Subject \\
\hline Declarative: non-finite: participle & Subject^Finite/Predicator \\
\hline Declarative: verbless: identification & Subject^Complement \\
\hline Declarative: verbless: classification & Complement^Subject \\
\hline Declarative: verbless: existence & Predicator^Subject \\
\hline Declarative: exclamative & WH- element^Subject \\
\hline Interrogative: finite: polar & Interrogative element $\wedge$ Finite/Predicator \\
\hline Interrogative: non-finite: infinitive abs./cons.: polar & Interrogative element^Finite/Predicator \\
\hline Interrogative: non-finite: participle: polar & Interrogative element^Subject \\
\hline Interrogative: verbless: identification: polar & Interrogative element^Subject \\
\hline Interrogative: verbless classification: polar & Interrogative element^Complement \\
\hline Interrogative: verbless: existence: polar & Interrogative element^Subject \\
\hline Interrogative: $\mathrm{WH}-$ & WH- element^^Subject \\
\hline Volitive & Predicator^Subject \\
\hline
\end{tabular}


The Mood element may also contain mood Adjuncts, which are described as adverbial groups expressing temporality, modality and intensity. Some aspects of modality and the verb are discussed, with the author noting a scholarly consensus that BH does not possess auxiliary verbs (cf. (Chrzanowski 2013)). One section each is dedicated to Mood in declarative, interrogative, volitive and in minor and elliptical clauses, ending with a brief discussion of extensions of Mood analysis. Much of the treatment in these sections deals with the order of constituents summarized in Table 2: the author includes examples of each Mood type and comments briefly on its structure.

Overall, Tatu (Tatu 2008) represents a valuable attempt to apply a systemic functional perspective to the description of the $\mathrm{BH}$ clause, and although it is somewhat limited in scope, it represents one of the only attempts at a description of the language's lexicogrammar. If indeed the description is somewhat tentative, this fact has been acknowledge by the author himself, and ought to be attributed to the fact that a systemic functional description of $\mathrm{BH}$ was not the main focus of the author's research. In summary, Bandstra (Bandstra 2008) provides a very detailed analysis of the text selected in his volume, but only a very general introduction to the theory behind the analysis, which befits its role as a students' guide to the text, whereas Tatu (Tatu 2008) provides a more substantial attempt at making explicit the lexicogrammar that lies behind his analysis. Although both of these texts will prove useful for anyone interested in the systemic functional description of Biblical Hebrew, the flaws described above demonstrate the need for an alternative account which more accurately describes the interpersonal resources available in Biblical Hebrew. An outline of such an account will be sketched in the following sections.

\section{Interpersonal meanings in Biblical Hebrew}

This section presents an account of the main features of the interpersonal grammar of the Biblical Hebrew clause. First, a dialogue will be presented and discussed, in order to outline the relationship between the basic speech functions on the semantic stratum and their realization in the lexicogrammatical resources at clause rank. Perhaps the motivation for certain aspects of the analysis will not be immediately clear; however, the details are explained more fully in the sections which follow. After this, a preliminary account of the system of MOOD TYPE and the elements involved in the Mood structure of the Hebrew clause will be outlined. Finally, the systems involved in modal assessment (POLARITY and MODALITY) will be described.

\section{Enacting social relationships}

As mentioned above, the interpersonal metafunction focuses on language as an element of dialogic exchange, and it is assumed that all languages possess resources for the exchange of meanings, either by means of propositions (exchange of information) or proposals (exchange of goods-\&-services). SFG proposes a relationship between the modes of meaning of the three metafunctions and their respective modes of expression. As regards the interpersonal metafunction, its mode of meaning is enactment, and its mode of expression is prosody, i.e. the organization of grammatical structure "characterized as running across more than one constituent" ((Matthiessen 2007): 778: Matthiessen et al. 1987: 33). The various systems that make up the system network of $\mathrm{MOOD}$ in $\mathrm{BH}$ serve to enact tenor relations between interactants in dialogue in the 
Hebrew text. The following edited dialogue ${ }^{3}$ will serve as a point of departure for the discussion of the basic speech functions and their realization in the Mood structure of the Hebrew clause. The dialogue begins when Saul and a servant are sent to look for his father's lost asses.

Saul to the servant:

[1] 1 Samuel 9.5

\begin{tabular}{lll}
\hline${ }^{e} \underline{k} \underline{a}$ & $w^{e}-$ & nāšûbōa \\
go-2MS-IMPV & and & return-1CS-COH \\
Finite/Predicator & conjunctive Adjunct & Finite/Predicator \\
Mood Base & & \\
(Let us turn back, $[\ldots])$ & & \\
\hline
\end{tabular}

The servant:

[2] 1 Samuel 9.6

\begin{tabular}{|c|c|c|c|}
\hline hinneh-nā' & iš & $\varnothing$ & bäir hazo't \\
\hline behold-please & man of God & (is) & in that city \\
\hline \multirow[t]{2}{*}{ Negotiator } & Subject & Finite/Predicator & circumstantial Adjunct \\
\hline & Mood Base & & Residue \\
\hline
\end{tabular}

[3] 1 Samuel 9.6

\begin{tabular}{lll}
\hline$w^{e}-$ & hä $\overline{i s}$ & nikbād \\
and & the man & be esteemed-MS-PART \\
conjunctive Adjunct & Subject & Finite/Predicator \\
& Mood Base & \\
(and the man is highly esteemed;) & & \\
\hline
\end{tabular}

[4] 1 Samuel 9.6

\begin{tabular}{lll}
\hline$k_{0}{ }^{a}$ šęr $y^{e} \underline{\text { daber }}$ & bô & yābôó \\
all that he says & come-INF.ABS & come-3MS-IMPF \\
Subject & Finite/Predicator & \\
Mood Base & \\
(everything that he says comes true.) & \\
\hline
\end{tabular}

[5] 1 Samuel 9.6

\begin{tabular}{lll}
\hline 'attâa & nel ${ }^{a} \underline{k} \hat{a}$ & šäm \\
now & go-1CP-COH & there \\
Negotiator & Finite/Predicator & circumstantial Adjunct \\
& Mood Base & Residue \\
(Let us go there;) & & \\
\hline
\end{tabular}


[6] 1 Samuel 9.6

\begin{tabular}{llll}
\hline ûlay & yagî́d & länû & 'ęt darkenû \\
perhaps & tell-3MS-IMPF & to us & our way \\
mood Adjunct & Finite/Predicator & Complement & Complement \\
Mood Base & & Residue & \\
(perhaps he will tell us about our errand $[\ldots])$ & & \\
\hline
\end{tabular}

Saul:

[7a] 1 Samuel 9.7

\begin{tabular}{lll}
\hline We $^{e}$ & hinneh & nelek \\
and & if & go-1CP-IMPF \\
conjunctive Adjunct & conjunctive Adjunct & Finite/Predicator \\
& & Mood Base \\
(But if we go,) & & \\
\hline
\end{tabular}

[7b] 1 Samuel 9.7

\begin{tabular}{llll}
\hline$u-$ & mah & näbî̀ & lāî̌ \\
and & what & bring-1CP-IMPF & to the man \\
conjunctive Adjunct & Complement (Negotiator) & Finite/Predicator & Complement \\
& Residue & Mood Base & Residue \\
(what can we bring the man?) & & \\
\hline
\end{tabular}

[8] 1 Samuel 9.7

\begin{tabular}{lll}
\hline mäh & $\varnothing$ & 'ittānû \\
what & (is) & with us \\
Subject & Finite/Predicator & Complement \\
Mood Base & & Residue \\
(What have we got?) & & \\
\hline
\end{tabular}

The servant:

[9] 1 Samuel 9.8

\begin{tabular}{|c|c|c|c|}
\hline hinneh & nimșā & $\underline{b}^{e} y \bar{a} d \underline{\imath}$ & rębóa šęqęl käsęp \\
\hline behold & be found- & in my hand & quarter shekel silver \\
\hline \multirow[t]{2}{*}{ Negotiator } & Finite/Predicator & circumstantial Adjunct & Subject \\
\hline & Mood Base & Residue & Mood Base \\
\hline
\end{tabular}


[10] 1 Samuel 9.8

\begin{tabular}{|c|c|}
\hline$\overline{w^{e} \text { nätatti }}$ & p iš hā \\
\hline give-1CS-WQTL & to the man of God \\
\hline Finite/Predicator & Complement \\
\hline Mood Base & Residue \\
\hline (I can give that to the man of God) & \\
\hline
\end{tabular}

[11] 1 Samuel 9.8

\begin{tabular}{lll}
\hline W'higîd & länû & 'ę darkenû \\
tell-3MS-WQTL & to us & our way \\
Finite/Predicator & Complement & Complement \\
Mood Base & Residue & \\
(and he will tell us about our errand.) & & \\
\hline
\end{tabular}

Saul:

[12] 1 Samuel 9.10

\begin{tabular}{|c|c|c|}
\hline țôb & $\varnothing$ & $d^{e} \underline{b} a \bar{r} r^{e} k \bar{a}$ \\
\hline good & (is) & your word \\
\hline Complement & Finite/Predicator & Subject \\
\hline Residue & Mood Base & \\
\hline (A good idea;) & & \\
\hline
\end{tabular}

[13] 1 Samuel 9.10

\begin{tabular}{lll}
\hline lek- & $-\hat{a}$ & nelek̂â \\
go-2MS-IMPV & EMPH & go-1CP-COH \\
Finite/Predicator & Negotiator & Finite/Predicator \\
Mood Base & & \\
(let us go.) & & \\
\hline
\end{tabular}

When they arrive at the city, the two meet some young women, whom they ask:

[14] 1 Samuel 9.11

\begin{tabular}{llll}
\hline$h^{a}-$ & yeš & bāzę & häro'ę \\
INTER & EXST & in this & the seer \\
Negotiator & Finite/Predicator & circumstantial Adjunct & Subject \\
& Mood Base & Residue & Mood Base \\
(Is the seer in this town?) & & & \\
\hline
\end{tabular}


The young women answer:

[15] 1 Samuel 9.12

\begin{tabular}{lll}
\hline yeš & hinneh & lep̄ānęykāa \\
EXST & behold & before you \\
Finite/Predicator & Negotiator & circumstantial Adjunct \\
Mood Base & & Residue \\
(There is.) & (Ahead of you.) & \\
\hline
\end{tabular}

If the interpersonal metafunction is described as a "mode of action" in that "the grammar enacts interpersonal relationships," it is because "dialogue is a process of exchanging meaning, in which the speaker is enacting [...] a particular interpersonal relationship, including his own role and the role he is assigning to the listener" ((Halliday \& Matthiessen 1999): 523-524). The interactants in any particular dialogue all contribute to its creation, "tak[ing] turns at this interactive process, each time adopting a speech role and assigning a complementary one to the other" ((Halliday \& Matthiessen 2014): 15).

In the conversation above, each speaker's turn represents an attempt to achieve something in the course of the conversation. In [1] Saul initiates the exchange by using a volitive clause in order to suggest that they return home, thus demanding goods\&-services from the servant. Instead of the expected acceptance of Saul's proposal, in [2] through [4] the servant replies by giving information, which leads to an alternative proposal in [5] and a modally assessed clause [6] indicating a possible result. Saul then objects to this proposal by means of questions in [7a and b] and [8], and the servant gives information in reply in [9] and then, in answer to the implied objection in Saul's questions, makes an offer to give goods-\&-services in [10], which will perhaps help them in the errand they have been sent on [11]. Saul then agrees in the first clause of [12] and issues another command in the second half. Of particular interest here is the absence of a pronomial Subject element for the speech roles of the two interlocutors, and the central role played by the various forms of the verbs for go and return as the negotiation unfolds, facts which are discussed in more detail below. From the interpersonal perspective, each move (realized by a single, free clause in the dialogue) represents an attempt to do or achieve something, with the interactants recognizing one another and the communicative acts that each of them have performed, and responding to them accordingly.

The interaction in this dialogue may be characterized as an exchange of either information or of goods-\&-services, and the nature of this exchange is such that these commodities are either given or demanded by the interlocutors in each move of the interaction. The first move, in example [1], is a command form which indicates a demand for goods-\&-services. This command is congruently realized by means of a volitive form. Examples [2] and [3], on the other hand, give information, and are congruently realized by declarative clauses, whereas the questions (demanding information) in examples [7], [8] and [14] are also congruently realized by means of interrogative clauses. Like many other languages, Biblical Hebrew did not develop a distinct, 
grammatical category for the realization of the semantic category of offers (giving goods-\&-services), and in example [10] the offer is realized by means of a declarative clause ((Halliday \& Matthiessen 2014): 139 and 195; Teruya et al. 2007: 868). The realization of the SPEECH FUNCTION systemic choices in the lexicogrammatical system of MOOD are summarized in Table 3 below. These are not intended as exhaustive of all the realizational possibilities available for each of these choices, but rather as typical, congruent realizations, using examples from the dialogue above.

\section{Mood type}

As in any other language, the MOOD system in Biblical Hebrew realizes at clause rank the systemic choices available in the semantic system of SPEECH FUNCTION. In the realization of different mood types, the main interpersonal zone of the clause is associated with the Finite/Predicator and the Negotiator, either separately or acting in combination, a claim which will be discussed in more detail in the following section. The purpose of the present section is to provide an account of the realization of Mood in the Biblical Hebrew clause, to supplement the general ideas presented in the previous section.

In $\mathrm{BH}$, the entry point to the system of MOOD TYPE is a free clause, and the principle contrast in the mood system is the distinction between indicative and volitive. The realization of this distinction is characterized by distinct verbal inflections for volitives and declaratives. The choice of volitive mood type leads to a further choice of volitive: imperative/cohortative/jussive. The imperative is associated with the second person, cohortative with the first person and jussive with the third (sometimes second) person ((van der Merwe et al. 1999): 150-152). The indicative option involves a further choice between declarative clauses and interrogative ones, and the interrogative option distinguishes between polar interrogatives and elemental interrogatives. Generally, the contrast between declarative and interrogative is realized by the presence in interrogative clauses either of the interrogative Negotiator $h^{a}$ - (polar) or of an interrogative proform which substitutes for a Subject, Complement or circumstantial Adjunct,

Table 3 Realization of SPEECH FUNCTION as MOOD

\begin{tabular}{|c|c|c|}
\hline & $\begin{array}{l}\text { Propositions (information) } \\
\searrow \text { indicative }\end{array}$ & $\begin{array}{l}\text { Proposals (goods- } \& \text {-services) } \\
\searrow \text { indicative and volitive }\end{array}$ \\
\hline \multirow[t]{5}{*}{ Giving } & $\begin{array}{l}\text { statement } \\
\searrow \text { indicative: declarative }\end{array}$ & $\begin{array}{l}\text { offer } \\
\searrow \text { indicative: declarative }\end{array}$ \\
\hline & [6] 'ûlay yagị̂ lānû 'ęt-darkenû & [10] wenätatti le iš hāelohîm \\
\hline & perhaps he will tell us about the errand & I can give that to the man of God \\
\hline & [3] w'hä îš nikgbād & \\
\hline & and the man is highly esteemed & \\
\hline \multirow[t]{6}{*}{ Demanding } & $\begin{array}{l}\text { question } \\
\searrow \text { indicative: interrogative: polar }\end{array}$ & $\begin{array}{l}\text { command } \\
\searrow \text { volitive: imperative }+ \text { cohortative }\end{array}$ \\
\hline & [14] hyeš bāzę hāro'ę & [13] lekâ nelekâa \\
\hline & Is the seer in town? & Let us go \\
\hline & $\begin{array}{l}\text { question } \\
\searrow \text { indicative: interrogative: elemental }\end{array}$ & $\begin{array}{l}\text { command } \\
\searrow \text { volitive: cohortative }\end{array}$ \\
\hline & [7] w'hinneh nelek umah-nnābî̀ lāî̌s & [5] 'attâ nelakâ ššăm \\
\hline & But if we go, what can we bring the man? & Let us go there. \\
\hline
\end{tabular}


depending the information being queried in an elemental interrogative. There is a general consensus that the typical constituent order of BH is VSO (Moshavi 2010), and Matthiessen (Matthiessen 2004) notes that in general "the verbal element [...] of the clause is likely to be the locus of interpersonal realizations [...] and/or to be associated with interpersonal adverbs or particles that serve as the locus of such realizations". Indeed, it is the verbal element Finite/Predicator which realizes the distinction between indicative and volitive in $\mathrm{BH}$; furthermore, both types of interrogatives are characterized by the presence of the above-mentioned interrogative elements in clause-initial position, which is clearly associated with prototypical verbal position in the constituent order of the clause, making the clause-initial position the most salient position in the juncture prosody of Biblical Hebrew. In summary, the prosodic patterns which relate to the least delicate distinctions in the $\mathrm{BH}$ mood system are realized by means of segments strongly associated with clause-initial position.

As mentioned above, the prototypical realization of mood types in Biblical Hebrew consists of either verbal inflection of the Finite/Predicator or the presence of Negotiators or similar elements. The following examples illustrate the distinction between volitive and indicative.

[16] Genesis 6.14

volitive: imperative

\begin{tabular}{lll}
\hline${ }^{a}$ śeh & $l^{e} k \underline{a}$ & tebat ${ }^{a}$ șey ḡop̄ęr \\
Make-2MS-IMPV & for you & ark of gopher wood \\
Finite/Predicator & circumstantial Adjunct & Complement \\
Mood base & Residue & \\
(Make yourself an ark of gopher wood) & & \\
\hline
\end{tabular}

[17] Joshua 11.18

indicative: declarative

\begin{tabular}{|c|c|c|c|c|}
\hline yāmîm rabîm & 'āśäh & $y^{e}$ hôšua & 'ęt kŏl hammeläkîm häellę & milhạânâ \\
\hline Many days & make-3MS-PERF & Joshua & with all those kings & war \\
\hline Circumstantial Adjunct & Finite/Predicator & Subject & circumstantial Adjunct & Complement \\
\hline Residue & Mood Base & & Residue & \\
\hline
\end{tabular}

These examples show clearly the realization of the distinction between indicative and volitive, using the same verbal root 's.s.h. ('make, do'), and also showing clearly the typically Semitic non-concatenative morphology in which changes in the internal vowel pattern indicate systemic choices in MOOD. In [16], the verbal element is located in its typical, clause-initial position, whereas in [17] it is preceded by a circumstantial Adjunct in thematic position. The realization of Mood selection is located in the inflectional morphology of the verbs, with 'aseh being a second- 
person masculine imperative, and 'áśăh differentiating itself as third-person masculine perfect form by means of the infixed vowel pattern $C \overline{\mathbf{a}} \mathbf{C} \mathbf{a} C$. While these differences are marked on the Finite/Predicator element, they serve to realize selections on the clause level, distinguishing in this case between volitive and indicative clause types. Differences in Finite/Predicator morphology also distinguish between the different volitive types, as shown in the following examples with the verbal root h.l.k. ('go, come, walk').

[18] 1 Samuel 20.42

volitive: imperative

\begin{tabular}{ll}
\hline lek & ̌šâlôm \\
Go-2MS-IMPV & in peace \\
Finite/Predicator & circumstantial Adjunct \\
Mood Base & Residue \\
(Go in peace.) & \\
\hline
\end{tabular}

[19] 2 Kings 6.2

volitive: cohortative

\begin{tabular}{lll}
\hline nel $^{l} \underline{k} \hat{a}$ & $-n \bar{a}$ & 'ad hayyarden \\
Go-1CP-COH & please & until the Jordan \\
Finite/Predicator & Negotiator & circumstantial Adjunct \\
Mood Base & & Residue \\
(Let us go to the Jordan) & & \\
\hline
\end{tabular}

Volitives may also be marked for POLITENESS by means of the Negotiator $-n \vec{a}$, which functions as a politeness marker, as in example [19] above and [20] below. Christiansen (Christiansen 2009) describes this Negotiator as a propositive particle when it accompanies a cohortative or jussive volitive, and as a politeness particle when it accompanies the imperative. In general terms, this Negotiator "has a softening effect on the speech segment conveyed to the addressee, suggesting that his response or compliance to the proposal is elective" (ibid. 392).

The masculine singular form of the imperative may also be marked by means of the morpheme - $\hat{a}$. Any discussion of the meaning associated with this form of the imperative, traditionally called the 'emphatic imperative', is problematic. Gesenius et al. (2006): 132) state that, while "[t]he shade of meaning conveyed" by this form "is not always so perceptible", it can be described as being "frequently emphatic". Joüon and Muraoka (Joüon \& Muraoka 1996) stress that this form "is emphatic in origin", although it does not appear to express any special nuance in meaning when compared to the unmarked form. They claim, furthermore, that the usage is inconsistent and may perhaps be due 
to "the interests of euphony" rather than to any precise semantic distinction relative to the unmarked form (ibid.). Van der Merwe et al. (van der Merwe et al. 1999) also emphasize that the semantic value of this marker is not known. Fassberg (Fassberg 1999), however, concludes that the imperative with $-\hat{a}$ is used "when the action of the verb is directed toward the speaker", or occurs "for the benefit of the speaker and his people", in contrast to action directed elsewhere. The present study will use the provisional term EMPHASIS to refer to the proposed system realized by this morpheme, while recognizing the shortcomings of such a general and unhelpful label. An example of an imperative clause marked for EMPHASIS is seen in example [21].

[20] 1 Samuel 9.3

volitive: imperative - politeness: marked

\begin{tabular}{|c|c|c|c|}
\hline qah & $n \bar{a}^{\prime}$ & $i t t^{e} k \bar{a}$ & 'ęt 'ahad mehann 'árîm \\
\hline Take-2MS-IMPV & please & with you & one of the young men \\
\hline Finite/Predicator & Negotiator & Circumstantial Adjunct & Complement \\
\hline \multicolumn{2}{|l|}{ Mood Base } & Residue & \\
\hline \multicolumn{4}{|c|}{ (Take along one of the servants) } \\
\hline
\end{tabular}

[21] Nehemiah 13.29

volitive: imperative - emphasis: marked

\begin{tabular}{llll}
\hline zŏkr & $-\hat{a}$ & lähęm & éohāy \\
Remember-2MS-IMPV & EMPH & to them & my God \\
Finite/Predicator & Negotiator & Complement & Vocative \\
Mood base & & Residue & \\
(Remember them, O my God [...]) & & & \\
\hline
\end{tabular}

The system of indicative type allows for selection between declarative and interrogative clause types. Declarative clauses are unmarked with respect to indicative type, whereas interrogative clauses are typically marked in various ways depending on the type. Elemental interrogatives are characterized by the presence of an interrogative proform, which can be assigned the functional role of Subject, Complement or Adjunct, depending on the nature of what is being queried. In example [22], the interrogative pro-form functions as the Subject in the Mood structure, while in [23] it functions as Complement and in [24] as an Adjunct. These pro-forms may also be described as Negotiators, following Thai (Thai 2004).

[22] Genesis 3.11

indicative: interrogative: elemental

\begin{tabular}{lll}
\hline$m \hat{\imath}$ & higîl & l'ḱā $^{k}$ \\
Who & tell-3MS-PERF & to you \\
Subject (Negotiator) & Finite/Predicator & Complement \\
Mood base & & Residue \\
(Who told you [that you were naked]?) & & \\
\hline
\end{tabular}


[23] Ecclesiastes 8.4

indicative: interrogative: elemental

\begin{tabular}{ll}
\hline ma & $\underline{\text { ta }{ }^{a} \text { śęh }}$ \\
What & make-2MS-IMPF \\
Complement (Negotiator) & Finite/Predicator \\
Residue & Mood base \\
(What are you doing?) & \\
\hline
\end{tabular}

[24] Exodus 5.15

indicative: interrogative: elemental

\begin{tabular}{|c|c|c|c|}
\hline lämmâ & ta $a^{a} \dot{s e q h}$ & koh & la $a^{a} b a ̄ d e y k \underline{a}$ \\
\hline Why & make-2MS-IMPF & thus & to your servants \\
\hline Circumstantial Adjunct (Negotiator) & Finite/Predicator & circumstantial Adjunct & Complement \\
\hline Residue & Mood base & Residue & \\
\hline \multicolumn{4}{|c|}{ (Why have you dealt thus with your servants?) } \\
\hline
\end{tabular}

In contrast, the mood type indicative: interrogative: polar is somewhat more complicated. Most grammars note that polar interrogatives may be either grammatically marked with the interrogative particle $h^{a}$ - or unmarked; in the latter case, it is presumed as likely (or sometimes merely asserted) that interrogative mood was marked by means of intonation, as in many other languages (Gesenius et al. 2006: 473; (Sperber 1943): 226; (van der Merwe et al. 1999): 322; (Waltke \& O'Connor 1990): 316; Joüon and Muraoka, 1993: 609). Indeed, Lipiński (Lipiński 1997) notes that rising intonation is one way of forming a question in Semitic languages in general, including ancient languages such as Babylonian, where the rising tone was indicated in the cuneiform script. However, Ancient Hebrew persists today as a written language which is no longer spoken natively, and therefore no data concerning the use of intonation in the realization of mood can be collected. In fact, Meister (Meister 1996) analyzes examples of the unmarked interrogative and casts doubt on the validity of this category in the description of Biblical Hebrew because intonation data is lacking, the examples analyzed can almost all be explained as statements, and none of them receives the expected reply in return. However, his study is restricted to a limited corpus and needs to be extended in order to validate the findings. Furthermore, Joüon and Muraoka (1996: 609) claim that sometimes the interrogative "appears further indicated by word-order". The examples cited, however, are unclear in that they are both relational: attributive (traditionally, classification) clauses with ellipsis of the Finite/Predicator and a constituent order of Complement $\wedge$ Subject, which is the usual constituent order of such a clause ((Waltke \& O'Connor 1990): 132). Therefore, it is difficult to understand how the order of constituents could be indicative of interrogative status. These issues are unresolved at present and require further investigation. If, however, the structures described in the previous paragraph are all taken into consideration, then the Biblical Hebrew polar interrogative would display the systemic features shown in Table 4 below. 
Table 4 Proposed systemic features in $\mathrm{BH}$ polar interrogative

\begin{tabular}{ll}
\hline Systemic features & Realization \\
\hline Grammatical prosody: juncture & interrogative Negotiator $h^{a}$ - \\
Grammatical prosody: internal & word-order \\
No grammatical prosody & intonation \\
\hline
\end{tabular}

The following example displays the typical realization of the polar interrogative by means of the interrogative Negotiator. Given the likely (but not completely clear) use of intonation to mark interrogatives in Biblical Hebrew, the interrogative Negotiator is located outside of the Mood Base and the Residue following Bardi's (Bardi 2008) argument regarding the cognate Negotiator in Arabic: since a polar interrogative may be realized without this particle, it is not part of the Mood Base. However, since this Negotiator "realizes the selection of Mood in the clause", there might be an argument for including it in the Mood Base ((Halliday \& Matthiessen 2014): 142). The structure of the Mood Base will be described in more detail in the following section.

[25] 1 Samuel 14.37

indicative: interrogative: polar

\begin{tabular}{lll}
\hline ha- & 'ered & 'a h. ${ }^{a}$ rê $\bar{p}^{e}$ lištîm \\
INTER & go down-1CS-IMPF & after Philistines \\
Negotiator & Finite/Predicator & circumstantial Adjunct \\
& Mood Base & Residue \\
(Shall I go down after the Philistines?) & & \\
\hline
\end{tabular}

Biblical Hebrew also uses this Negotiator together with the conjunctive Adjunct 'im to realize an alternative question, as in [26] below.

[26] 1 Kings 22.15

indicative: interrogative: polar

\begin{tabular}{|c|c|c|c|c|c|}
\hline$\overline{h^{a}-}$ & nelek & 'ęl rāmoț gil'ād & lammilhāmâ & $\mathrm{im}$ & nęhdāal \\
\hline INTER & go-1CP-IMPF & to Ramoth-Gilead & to war & or & refrain-1CP-IMPF \\
\hline \multirow[t]{2}{*}{ Negotiator } & Finite/Predicator & $\begin{array}{l}\text { circumstantial } \\
\text { Adjunct }\end{array}$ & $\begin{array}{l}\text { circumstantial } \\
\text { Adjunct }\end{array}$ & $\begin{array}{l}\text { conjunctive } \\
\text { Adjunct }\end{array}$ & Finite/Predicator \\
\hline & Mood Base & Residue & & & Mood Base \\
\hline
\end{tabular}

This section has presented the main types of selection available in the BH system of MOOD TYPE, providing examples of how these options are realized in the mood structure of the clause. The analyses above have shown that the realization of interpersonal meanings in the clause is mostly concentrated around the Negotiator and Finite/Predicator elements, in that these elements are the most important for the selection of mood in the clause. In elemental interrogatives, the various interrogative pro-forms are also central, and may be analyzed as Negotiators or according to the underlying functional roles of the elements 


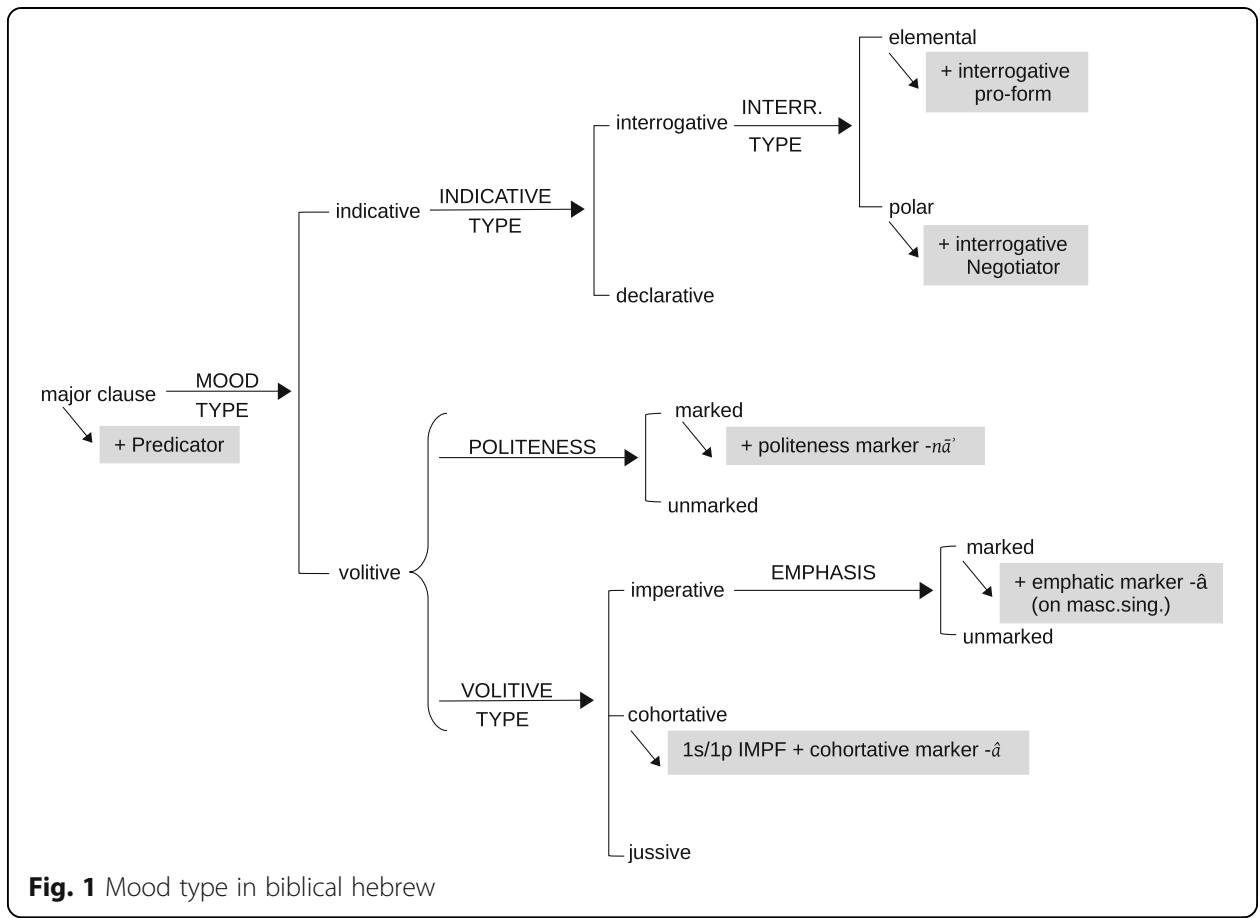

which are being queried. The next section will show that the Finite/Predicator is the central element in the mood structure, the element which "carries the burden of the clause as an interactive event" ((Halliday \& Matthiessen 2014): 150), although the various Negotiators serve to realize certain more delicate distinctions in mood. Based on these analyses, a provisional system network can be formulated, as shown in Fig. 1 below.

\section{Encoding interpersonal meanings}

This section will describe the elements which make up the mood structure of the BH clause, and how these individual elements serve to encode interpersonal meanings in the realization of the choices available in the Mood system as described in the previous section. Where the previous section was focused on establishing the systemic choices available in the Mood type system, the present section aims to provide more detail regarding the structural elements by means of which the system is realized. First, a general description of the Mood structure will be outlined, followed by a discussion of the elements of which this structure is constituted.

\section{Mood structure}

In order to look more closely at the mood structure of the clause, the following fragment of dialogue will serve as an entry point.

Abraham said:

[27] Genesis 18.24

\begin{tabular}{|c|c|c|c|}
\hline ûlay & yeš & $h^{a}{ }^{a}$ iššìm șaddîqim & $b^{e} \underline{\text { tôk }}$ hāîr \\
\hline Perhaps & EXST & fifty innocent & within the city \\
\hline Mood Adjunct & Finite/Predicator & Subject & circumstantial Adjunct \\
\hline \multicolumn{3}{|l|}{ Mood Base } & Residue \\
\hline \multicolumn{4}{|c|}{ (Perhaps there are fifty innocent within the city;) } \\
\hline
\end{tabular}


[28] Genesis 18.24

\begin{tabular}{|c|c|c|c|c|c|c|}
\hline$\overline{h a-}$ & 'aṕp & tispę & $w^{e}-$ & $10^{\prime}$ & tiśśśa' & lammāqôm \\
\hline INTER & then & sweep away-3MS-IMPF & and & NEG & forgive-3MS-IMPF & the place \\
\hline \multirow[t]{2}{*}{ Negotiator } & $\begin{array}{l}\text { conjunctive } \\
\text { Adjunct }\end{array}$ & Finite/Predicator & $\begin{array}{l}\text { conjunctive } \\
\text { Adjunct }\end{array}$ & $\begin{array}{l}\text { mood } \\
\text { Adjunct }\end{array}$ & Finite/Predicator & Complement \\
\hline & & Mood- & & Base & & Residue \\
\hline
\end{tabular}

(will You then wipe out the place and not forgive it [for the sake of the innocent fifty within it?])

And God said:

[29] Genesis 18.26

\begin{tabular}{|c|c|c|c|c|}
\hline $\mathrm{im}$ & 'ęmșà' & bis ${ }^{e} d o m$ & $h^{a}$ miššìm șaddîqim & $b^{e}$ tôk hāîr \\
\hline If & find-1CS-IMPF & in Sodom & fifty innocent & within the city \\
\hline \multirow[t]{2}{*}{ Conjunctive Adjunct } & Finite/Predicator & circumstantial Adjunct & Complement & circumstantial Adjunct \\
\hline & Mood Base & Residue & & \\
\hline
\end{tabular}

[30] Genesis 18.26

\begin{tabular}{|c|c|c|}
\hline$w^{e} n \bar{a} \bar{s}^{a}{ }^{\prime} \underline{1} \hat{~}$ & I'kŏl hammäqôm & ba $a^{a}$ burräm \\
\hline Forgive-1CS-WQTL & to all the place & for sake-them \\
\hline Finite/Predicator & Complement & circumstantial Adjunct \\
\hline Mood Base & Residue & \\
\hline \multicolumn{3}{|c|}{ (I will forgive the whole place for their sake.) } \\
\hline
\end{tabular}

\section{Abraham said:}

[31] Genesis 18.28

\begin{tabular}{llll}
\hline ûlay & yahs ${ }^{e}$ rûn & $h^{a}$ miššim hașsaddîaim & $h^{a}$ miššâ \\
Perhaps & lack-3MP-IMPF & the fifty innocent & five \\
Mood Adjunct & Finite/Predicator & Subject & Complement \\
Mood Base & & Residue \\
(Perhaps the fifty innocent shall lack five?) & & \\
\hline
\end{tabular}

\section{[32] Genesis 18.28}

\begin{tabular}{|c|c|c|c|}
\hline$\overline{h^{a}-}$ & tašhît & 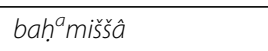 & 'ęt kŏl hāîr \\
\hline INTER & destroy-2MS-IMPF & on the five & all the city \\
\hline \multirow[t]{2}{*}{ Negotiator } & Finite/Predicator & circumstantial Adjunct & Complement \\
\hline & Mood Base & Residue & \\
\hline
\end{tabular}


And God said:

[33] Genesis 18.28

\begin{tabular}{|c|c|c|c|c|c|}
\hline$\overline{10}$ & 'ašhît & im & 'ęmșā' & šām & 'arbāîm wah ${ }^{a}$ miššâ \\
\hline NEG & $\begin{array}{l}\text { destroy-1CS- } \\
\text { IMPF }\end{array}$ & if & find-1CS-IMPF & there & forty-five \\
\hline Mood Adjunct & $\begin{array}{l}\text { Finite/ } \\
\text { Predicator }\end{array}$ & $\begin{array}{l}\text { conjunctive } \\
\text { Adjunct }\end{array}$ & $\begin{array}{l}\text { Finite/ } \\
\text { Predicator }\end{array}$ & $\begin{array}{l}\text { circumstantial } \\
\text { Adjunct }\end{array}$ & Complement \\
\hline \multicolumn{3}{|l|}{ Mood Base } & Mood Base & Residue & \\
\hline \multicolumn{6}{|c|}{ (I will not destroy if I find forty-five there.) } \\
\hline
\end{tabular}

The above text is perhaps one of the most famous examples of negotiation in the Biblical text: Abraham's attempt to bargain with God over the fate of the people of Sodom. Abraham first presents a modally-assessed statement introduced by the modal Adjunct 'ûlay as a possible reality and then introduces a question with the interrogative Negotiator particle $h^{a}{ }^{a}$. God answers each question with a conditional introduced by the conjunctive Adjunct ' $\mathrm{im}$, and a statement of what He will do if the condition is met.

In this interaction, the elements in bold deserve special attention as they represent the component of the clause which carries the argument forward, or "carries the burden of the clause as an interactive event" ((Halliday \& Matthiessen 2014): 150). In somewhat simplified terms, this element includes a Predicator (which realizes the Process, or lexical content of the verbal group) and a Finite element (which realizes tense/aspect, person, gender and number). Furthermore, the Predicator is also marked for voice and type of action by means of the stem conjugation system traditionally referred to as binyanim. In the interaction presented above, it should be noted that the elements in bold are not associated with an explicit Subject. This is because BH encodes information about the Subject in the morphology of the Finite/Predicator element, thus representing an example of "the Mediterranean model of registering the Subject on the finite verb but not requiring its structural presence (as in Spanish, Portuguese, Italian, Greek and Arabic)" (Teruya et al. 2007: 912).

In example [32] above, the Hebrew consonantal root š.h.t. in the hif'il stem conjugation realizes a material process with the English translation 'destroy', as encoded in the morpheme -šhît. The prefix ta $a$-, on the other hand, encodes indicative mood as well as a future/imperfect form of tense/aspect. Furthermore, this same prefix also encodes the Subject as second-person, and the lack of a feminine or plural suffix indicates that the Subject is masculine singular. In comparison, the response in example [33] picks up the same Predicator morpheme -šh $h \underline{t}$, , but introduces changes in the Finite element, represented by the prefix ' $a$-. In this case, the prefix specifies the same future/imperfect form of tense/aspect, but encodes the Subject as first-person common gender singular.

This element which carries the argument forward will be called the Mood Base in this study, following the usage in Bardi's (Bardi 2008) description of Arabic, since the mood structures of these two Semitic languages display marked similarities. The central element of the Mood Base is the Finite/Predicator, while the Subject plays a secondary role inasmuch as its explicit presence is not obligatory in the clause. The Mood Base may also contain mood Adjuncts and Negotiator particles. Outside of the Mood Base, the Residue of the 
clause contains any Complements and circumstantial Adjuncts; furthermore, some elements relevant to interpersonal interaction lie outside of the Mood Base and Residue, including Vocatives, Expletives, comment Adjuncts and certain Negotiators.

The main interpersonal zone of the clause is found in the Mood Base, and in particular in the Finite/Predicator. Although the Mood Base also contains the Subject and mood Adjuncts, the main features active in the realization of interpersonal meanings are the Finite/Predicator and the Negotiator. Although the interrogative Negotiator might be included in the Mood Base, it will be regarded as outside the Mood Base for the reasons outlined in the discussion of polar interrogatives in section Mood type above. This element of the mood structure is different from the Mood element found in descriptions of English in that it also includes the Predicator, the Subject is not an essential element, and the relative ordering of Subject and Finite is not relevant to the realization of the MOOD system. Teruya et al. (2007): 912-913 ) propose a cline at the poles of which are found Mood-based and Predicator-based languages, as shown in Table 5.

According to the analysis presented here, Biblical Hebrew would fall closer to the Predicatorbased pole, somewhere between the Finite ^ Predicator languages such as Spanish and the Predicator + Negotiator languages such as Chinese and Japanese. While the Finite/Predicator is the central element found in the Mood Base, it may also contain an explicit Subject, Negotiator(s), and mood Adjunct(s), each of which is discussed in turn below.

Finite/Predicator Looked at from above, the Finite/Predicator is that part of the Mood structure which specifies the process involved in the clause. The Finite/Predicator element is realized by a verbal group, which is marked for person, gender, number and tense/aspect. The exact nature of the tense/aspect feature is one of the most contentious issues in $\mathrm{BH}$ linguistics, with some scholars arguing for a tense-based verbal system and others for an aspect-based one, or some combination thereof; the terms of this system are often labeled in various ways, depending on the theoretical positions of the individual researcher (Waltke and O'Connor, 1990: 455-478). For the sake of convenience, the present work labels the two main forms perfect and imperfect, while the waw-prefixed forms are labeled with their formal descriptive labels weqatal and wayyiqtol. There is a further system of verbal forms, traditionally referred to as binyanim, which are generally considered realizations of voice and type of action, although there is disagreement in the literature as to the nature of the meanings associated with each binyan as well (ibid. 343-361). While the disagreements and controversies related to the $\mathrm{BH}$ verbal system have been duly noted, any

Table 5 Classification of mood structures

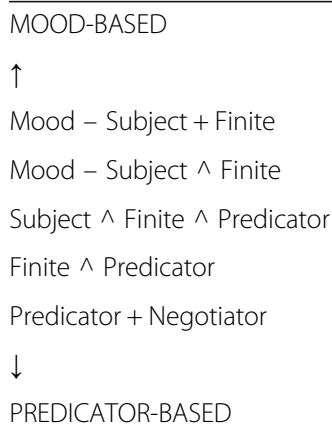


attempt at their resolution or the development of an original account, or even a description of their basic functions, are beyond the scope of the present study. It should be noted, however, that the perfect, imperfect, weqatal and wayyiqtol are typically associated with the selection of indicative mood type (although the imperfect is also the normal form for imperatives which select for negative POLARITY); however, the imperfect and weqatal commonly realize various modal meanings as well (Gianto 1998).

The Finite/Predicator may be realized by verbal group consisting of a single verb, or by a verbal group consisting of more than one verb. In the $\mathrm{BH}$ clause, the Finite and Predicator elements are normally fused and do not function separately in the clause, unlike in English; however, in certain cases they may be realized separately. Realized as separate elements, the Finite includes marking for person, gender, number and tense/ aspect, while the Predicator is typically realized by means of one of the infinitive forms. This structure is described as "auxiliary + infinitive" (Chrzanowski 2013: 246 ). In some cases, however, BH uses a "two-finite-verb construction", in which both the auxiliary and the lexical verb are fully inflected as if they were two separate clauses (ibid.).

[34] Genesis 1.1

\begin{tabular}{|c|c|c|c|}
\hline$\overline{b^{e} r e^{\prime} s \hat{i} \underline{t}}$ & bärā' & Elohîm & 'et hašämayim w'eț hä'äręs \\
\hline In beginning & create-3MS-PERF & God & the heavens and the earth \\
\hline Circumstantial Adjunct & Finite/Predicator & Subject & Complement \\
\hline Residue & Mood base & & Residue \\
\hline
\end{tabular}

[35] 2 Samuel 14:10

\begin{tabular}{|c|c|c|c|c|c|}
\hline$w^{e}$ & $10^{\prime}$ & yosî̄ & 'ôd & lāḡáat & bäk \\
\hline And & NEG & add-3MS-IMPF & again & hurt-INF.CONS & in you \\
\hline \multirow[t]{2}{*}{ Conjunctive Adjunct } & mood Adjunct & Finite & mood Adjunct & Predicator & \\
\hline & Mood base & & & & Residue \\
\hline
\end{tabular}

The first example above shows a simple realization of the Finite/Predicator, in which the element consists of a single verb. The second example, however, displays a more complex structure, in which two different verbs participate in the Finite/Predicator structure. In this case, the first verb realizes features associated with Finite in that it is inflected for person, gender, number and aspect/tense, whereas the second is an infinitive construct preceded by the preposition $l$-, and represents the main process associated with the Predicator function. In the first example, the single verb $b \bar{a} r \bar{a}$ includes both the elements associated with Finite (person, gender, number and aspect/tense) as well as with process type. While the verb yosî̄ in the second example does not indicate the process type, it does however specify the phase of the process specified by the non-finite verb, indicating "repetition as an addition to, or an extension of, an earlier event", although the verb is often most accurately translated with the adverb "again", and is often 
reinforced by means of the adverbial ôd ('again') (Chrzanowski 2013: 247). On Chrzanowski's view, most BH auxiliary verbs are of this type; i.e. they specify the phase of the process indicated by the Predicator verb. However, the auxiliary + infinitive construction above is not the only structure available in Hebrew: a similar relationship may be expressed by means of a two-finite-verb construction, depending on the auxiliary in question as well as other factors (ibid., 246), as shown in the following example.

[36] Genesis 26.18

\begin{tabular}{llll}
\hline wayyāšäb & yișhāa & wayyahpor & 'ęt be'erot hammayim \\
Do again-3MS-WYQTL & Isaac & dig-3MS-WYQTL & the wells of water \\
Finite & Subject & Finite/Predicator & Complement \\
Mood base & & Residue \\
(Isaac dug anew the wells [...]) & & \\
\hline
\end{tabular}

The verb wayyāšäb above is a grammaticalized form of a lexical verb whose meaning is "return", but in examples like this, the two finite verbs function as a single meaning unit, even though they superficially seem to be two separate coordinate clauses (ibid.).

In addition to the phasal meanings shown above, $\mathrm{BH}$ also possesses two auxiliary verbs with modal meanings: $y \bar{a} \underline{k} o l$ - 'can, to be able' - and 'āba $\bar{a} h$ - 'be willing, want' (ibid., 245), which exhibit similar structural realizations, as shown in the following two examples.

[37] Genesis 44.26

\begin{tabular}{lll}
\hline $10^{\prime}$ & nûkal & lärędęț \\
NEG & can-1CP-IMPF & descend-INF.CONS \\
Mood Adjunct & Finite & Predicator \\
Mood base & & \\
(We cannot go down $[\ldots])$ & & \\
\hline
\end{tabular}

[38] Joshua 24.10

\begin{tabular}{|c|c|c|c|c|}
\hline$\overline{w^{e}}$ & $10^{\prime}$ & 'äboîtî & lišmoa' & lebil'äm \\
\hline But & NEG & be willing-1CS-PERF & listen-INF.CONS & to Balaam \\
\hline \multirow[t]{2}{*}{ Conjunctive Adjunct } & mood Adjunct & Finite & Predicator & Complement \\
\hline & Mood base & & & Residue \\
\hline ([...] but I refused to & to Balaam) & & & \\
\hline
\end{tabular}

The examples above illustrate why the present account follows Matthiessen's (Matthiessen 2004): 544-545) discussion of Arabic in describing a generally fused Finite and Predicator element, which may however in certain cases be separated. For example, the 
Predicator verb may be in ellipsis, when it is understood in the context, as in the following exchange.

[39] Genesis 29.7

\begin{tabular}{lllll}
\hline hašqû & hașón & $\hat{u}-$ & $l^{e} \underline{k} \hat{u}$ & $r^{e} \hat{u}$ \\
water-2MP-IMPV & the flock & and & go-2MP-IMPV & pasture-2MP-IMPV \\
Finite/Predicator & Complement & conjunctive Adjunct & Finite/Predicator & Finite/Predicator \\
Mood base & Residue & & Mood base & \\
(water the flock and take them to pasture) & & \\
\hline
\end{tabular}

[40] Genesis 29.8

\begin{tabular}{lll}
\hline wayyo'merû & $10^{\prime}$ & nûkal \\
Say-3MP-WYQTL & NEG & can-1CP-IMPF \\
Finite/Predicator & mood Adjunct & Finite \\
Mood base & Mood base & \\
1: Quoting & 2: Quoted & \\
(But they said, "We cannot") & & \\
\hline
\end{tabular}

Although Bandstra analyzes the infinitive construct preceded by the preposition $l^{e}$ - as a prepositional phrase, apparently following the traditional designation of the infinitive forms as verbal nouns, the present study follows Chrzanowski (2013): 246), who analyses it as a verbal form in which $l^{e}$ - is a grammaticalized infinitive marker instead of a preposition introducing a prepositional phrase. Genesis 4.2 shall serve as an example.

[41] Genesis 4.2

\begin{tabular}{lll}
\hline wattosęp & lälędęt & 'ęt 'ähîu 'ęt hābęl \\
Add-3FS-WYQTL & give birth-INF.CONS & his brother Abel \\
Finite & Predicator & Complement \\
Mood base & & Residue \\
(She then bore his brother Abel) & & \\
\hline
\end{tabular}

In this example, Bardi (2008): 229-230) analyses the infinitive construct as a prepositional phrase; furthermore, since Bandstra's account of Mood does not include the concept of a Predicator, the verb lälędęt does not have have a functional role in the Mood structure, although the verb wattose $e \bar{p}$ is labeled Finite, as in the analysis above. In addition, his analysis of the Transitivity structure assigns the Process function to wattosęp but not to lälędęt, although he also analyses the latter as a preposition + process, and adds that the verbal group complex "is a way of combining two processes into one" (ibid. 230). The analysis given above, on the other hand, clearly distinguishes the primary Process (indicated by the Predicator) from the auxiliary verb functioning as Finite, which in this case indicates the reiteration of the Process. 
A complex Finite/Predicator unit may also be realized by a verbal group complex with a finite verb either preceded or followed by an infinitive absolute of the same verbal root, as the bound clause in [42a] shows.

[42a] Genesis 2.17

\begin{tabular}{llll}
\hline$k \hat{\imath}$ & $b^{e}$ yôm ${ }^{x a k o ̆ l k a ̆ ~ m i m m e ̨ n n u ̂ ~}$ & môt & tāmût \\
For & in the day of your eating from it & die-INF.ABS & die-2MS-IMPF \\
Conjunctive Adjunct & circumstantial Adjunct & Finite/Predicator & \\
& Residue & Mood Base & \\
(for as soon as you eat of it, you shall die) & & \\
\hline
\end{tabular}

The placement of the infinitive absolute before the finite verb (Finite/Predicator) typically expresses a high degree of certainty on the part of the speaker, thus grammaticalizing modalization in the verbal group (van der Merwe et al. 1999: 158; Waltke and O'Connor 1990: 584-488). Tatu (2008): 184) analyzes this clause differently, as shown below.

[42b] Genesis 2.17 - Tatu's analysis

\begin{tabular}{|c|c|c|c|c|}
\hline$\overline{k \hat{\imath}}$ & $b^{e}$ yôm ${ }^{a}$ kŏlkā & mimmęnnû & môt & tāmût \\
\hline For & in the day of your eating & from it & [you] will & die \\
\hline \multirow[t]{2}{*}{ Adj } & Adjunct & Adjunct & Finite & Predicator \\
\hline & Residue & & Mood & Residue \\
\hline
\end{tabular}

Tatu claims that the infinitive absolute (môt ) here, which accompanies a finite form of the same root verb, plays the role of Finite; however, the elements associated with the Finite, i.e. person and tense, are morphologically part of the second-person masculine imperfect verb form tämût, and not the infinitive absolute form môt; therefore, it makes little sense to analyze the infinitive absolute as the Finite and the finite verb as the Predicator. This fact is obscured in Tatu's gloss, where the English Finite operator will and the second person pronoun are associated with the infinitive absolute form instead of the word where those elements are realized morphologically. As far as this example is concerned, Bandstra, Barry (2008): 145) analysis of the infinitive absolute as a modal Adjunct expressing certainty seems much more apt, since this structure does indeed express certainty, although since it is a verbal form, it would seem more appropriate to locate this word within the verbal group complex.

It should also be noted that the Finite/Predicator in BH may also include a pronomial suffix that represents the Complement of the clause. In such cases both the Subject and the Complement are marked morphologically on the verb, and may be represented in the following manner: Finite/Predicator ${ }_{[\mathrm{S}, \mathrm{C}]}$ (Matthiessen 2004: 544-545).

[43] Genesis 4.8

wayyahargehû

Finite/Predicator $[\mathrm{S}, \mathrm{C}]$

Mood base (+ Residue)

([...] he killed him.) 
The single-word clause in [43] can be divided at morpheme rank into four parts: wa-yyaharge-h $\hat{u}$. The central morpheme that indicates the process involved in the clause is harge (kill), while the prefix yya-is the third-person masculine singular imperfect marker and the suffix - hî marks a third-person masculine singular Complement. The initial morpheme, wa-, is a grammaticalised form of the conjunctive Adjunct $w^{e}$-, which is part the indicative verb form referred to as the wayyiqtol. In most cases, the analyses in the present study do not indicate the presence of the Subject in subscript, because most forms of BH verbs include the Subject by default.

$\mathrm{BH}$ texts also present certain types of relational clauses in which there is no verbal element present. These are traditionally considered a separate type of clause, and Tatu (2008): 182-183) system of Mood type discussed above accepts this traditional division. Sinclair (1999), however, demonstrated that there is no need to hypothesize a distinct clause type for verbless clauses, because the various structures they exhibit are identical to verbal relational clauses in which the copula hāyāh is present. The present study follows Sinclair in assuming that such verbless clauses are not a distinct clause type, but manifest ellipsis of the copula under certain conditions. In the following example, the Finite/Predicator in ellipsis is represented by the symbol $\varnothing$.

[44] 2 Kings 2.19

\begin{tabular}{llll}
\hline$w^{e}-$ & $\begin{array}{l}\text { hammayim } \\
\text { the water }\end{array}$ & $\varnothing$ & räím \\
And & Subject & (is) & bad \\
Conjunctive Adjunct & Food base & & Complement \\
& & Residue \\
(... but the water is bad ...) & & \\
\hline
\end{tabular}

Finally, it should also be noted that clauses in which the process type is existential may have either the positive or negative predicator of existence as the Finite/Predicator element, as in examples [45] and [46]. Both of these inflect for person, gender and number, as may be seen in example [47], where the negative predicator stands alone, and in [48] where the inflected positive predicator is used together with a participle. The negative existential predicator also functions to negate a participle, as shown in example [49]. In examples [48] and [49], the predicator of existence is analyzed as Finite and the lexical verb is analyzed as constituting the Finite/Predicator element, because both elements are inflected, the particle for person, gender and number, and the lexical verb for gender and number; therefore, the lexical verb also displays features associated with the Finite element. Differently from examples [45] through [47], however, where the existential predicator indicates an existential process type, in [48] and [49] the existential predicator serves as a positive or negative Finite element, which carries the inflection for person that is absent from the BH participle form. In this case, the Subject is indicated by means of the same pronomial suffixes which represent the Complement when they occur on other verbs.

[45] Ezra 10.2

\begin{tabular}{|c|c|c|c|c|c|}
\hline$\overline{w^{e}-}$ & 'attâ & yeš & miqwę & leyiśrāel & 'al zo't \\
\hline But & now & EXST & hope & for Israel & on this \\
\hline Conjunctive Adjunct & Negotiator & $\begin{array}{l}\text { Finite/Predicator } \\
\text { Mood base }\end{array}$ & Subject & $\begin{array}{l}\text { circumstantial Adjunct } \\
\text { Residue }\end{array}$ & circumstantial Adjunct \\
\hline
\end{tabular}


[46] Numbers 5.13

\begin{tabular}{llll}
\hline$w^{e}-$ & éd & ên & bāh \\
And & witness & EXST.NEG & in her \\
Conjunctive Adjunct & Subject & Finite/Predicator & Complement \\
& Mood base & & Residue \\
(and there is no witness against her) & & & \\
\hline
\end{tabular}

[47] Genesis 5.24

\begin{tabular}{ll}
\hline$w^{e}-$ & 'ênęnnû \\
And & EXST.NEG-3MS \\
Conjunctive Adjunct & Finite/Predicator [S] \\
& Mood base \\
(then he was no more) & \\
\hline
\end{tabular}

[48] Genesis 43.4

\begin{tabular}{|c|c|c|c|c|}
\hline $\mathrm{im}$ & yeše $k a \bar{a}$ & $m^{e}$ šalleah & 'ęt 'ähînû & ittānû \\
\hline If & EXST-2MS & send-MS-PART & our brother & with us \\
\hline \multirow[t]{2}{*}{ Conjunctive Adjunct } & Finite & Finite/Predicator & Complement & circumstantial Adjunct \\
\hline & Mood base & & Residue & \\
\hline
\end{tabular}

[49] Esther 3.8

\begin{tabular}{llll}
\hline$w^{e}-$ & 'ęt dätê hammęlęk & 'ênäm & 'osîm \\
And & the king's laws & EXST.NEG-3MP & keep-3MP-PART \\
Conjunctive Adjunct & Complement & Finite & Finite/Predicator \\
& Residue & Mood base & \\
(and they do not obey the king's laws) & & \\
\hline
\end{tabular}

Subject The Subject is typically realized by a nominal group and provides "something by reference to which the proposition can be affirmed or denied," that is, "the entity in respect of which the assertion is claimed to have validity" ((Halliday \& Matthiessen 2014): 145-146). Unlike English, but like Arabic, Spanish and Italian, an explicit Subject is not necessary in BH because the Subject is encoded in the verbal morphology, as discussed in the previous section. Therefore, when compared to the English Subject, the Subject element in BH carries a relatively low functional load, given that it is not an obligatory element of the clause structure. For clauses with no explicit Subject, see examples [28] to [33] above. A nominal Subject may be present, however, where modal responsibility needs to be attributed to a particular entity in the exchange context, and 
where that entity has not already been established as understood in the context. An example of this type of structure is shown in example [50]. The explicit occurrence of a pronomial Subject often has an emphatic value ((Blau 1993): 89). This emphatic value is said to arise from the repetition of information: "[s]ince finite verbs have affixes which indicate the person, number and gender of the subject, one could also say that an explicit subject is a repetition or more precise specification of the 'built-in' subject" ((van der Merwe et al. 1999): 247). This phenomenon may be seen in example [51] below, where the translation indicates this emphatic pronoun by means of the English locution It was I who [...]. Finally, explicit Subjects, whether nominal or pronomial, are required in those relational clauses in which the Finite/Predicator element is in ellipsis, as in example [52].

[50] Joshua 3.1

\begin{tabular}{|c|c|c|}
\hline wayyaškam & $y^{e} h o ̂ s ̌ u a c$ & babogęr \\
\hline Get up early-3MS-WYQTL & Joshua & in the morning \\
\hline Finite/Predicator & Subject & circumstantial Adjunct \\
\hline Mood base & & Residue \\
\hline (Joshua got up early in the morning) & & \\
\hline
\end{tabular}

[51] 2 Samuel 12.7

\begin{tabular}{|c|c|c|c|}
\hline 'ānokî̀ & $m^{e}$ šahtîk $^{\prime}$ & emęlęk & 'al yiśräel \\
\hline । & anoint-1MS-PERF + 3MS & to king & over Israel \\
\hline Subject & Finite/Predicator $[s, c]$ & circumstantial Adjunct & circumstantial Adjunct \\
\hline \multicolumn{2}{|c|}{ Mood base (Residue) } & Residue & \\
\hline (It was I & red you king over Israel) & & \\
\hline
\end{tabular}

[52] 2 Samuel 12.7

\begin{tabular}{|c|c|c|}
\hline 'attâ & $\varnothing$ & hāiš \\
\hline You & (are) & the man \\
\hline Subject & Finite/Predicator & Complement \\
\hline Mood base & & Residue \\
\hline (You are the man) & & \\
\hline
\end{tabular}

Negotiator The term Negotiator may be a source of confusion, as it has been used in different ways in the systemic functional descriptive literature. In Caffarel's (Caffarel 2006) grammar of French, the term refers to the element of mood structure consisting of the three functions Subject, Finite and Predicator, which is similar to the English Mood element described above in section Mood. The present study, however, follows Halliday and Matthiessen (Halliday \& Matthiessen 2014), who use the term to refer to 
interpersonal mood particles which serve to realize distinctions in mood in languages other than English. Since this function is not relevant to the description of English, the authors do not discuss it in any detail, and in order to obtain a clearer understanding one must turn to descriptions of other languages and discussions of systemic functional typology more generally.

The Negotiator function is one of several ways in which interpersonal meanings may be realized. For example, distinctions in mood are realized by means of three main types of prosody: sequential, intonational and segmental ((Matthiessen 2004): 564). The Negotiator function represents a type of segmental realization of mood distinction, in that a segment is added to the clause in order either to realize a distinction in MOOD TYPE or to indicate other interpersonal features of the clause. Matthiessen (Matthiessen 2004) notes that, crosslinguistically, the Negotiator function is realized by mood particles, which are various particles "indicating mood and other interpersonal features". Whereas Adjuncts are more varied in their realizational possibilities, in that they may be realized by adverbial groups/particles, prepositional phrases and nominal groups, Negotiators are limited to particles.

The Negotiator is an element which embodies the negotiatory value of the clause. In $\mathrm{BH}$, the Negotiator tends to be realized either as a juncture prosody towards the beginning of the clause or after the Finite/Predicator element. Teruya (Teruya 2004) defines the Negotiator in the Japanese clause as that element which "adds the negotiatory or attitudinal value of clause such as question, insistence or assertion". Thai's (Thai 2004) account of Vietnamese describes the Negotiator as "realized by one of the interpersonal particles: polar interrogative particles, elemental interrogative items or imperative particles", which includes not only particles as traditionally understood, but also interrogative pro-forms which might be analyzed as Subject, Complement or Adjunct according to their functions in the clause. For examples of interrogative pro-forms which may be interpreted as Negotiators, see examples [22] through [24] above. BH also utilizes certain attitudinal Negotiators as well. These include the politeness marker $n \bar{a}$ and the emphatic marker $-\hat{a}$ discussed above in examples [20] and [21].

Another example of a $\mathrm{BH}$ Negotiator is the particle hinneh, typically translated as 'behold', which Waltke and O'Connor (Waltke \& O'Connor 1990) refer to as a "particle of interest". This particle serves to draw the attention of the interlocutor either to some part of the clause or some aspect of the context. The focus of attention may be on some event which is "surprising or unexpected for the person addressed", or else on the speaker, who presents him/herself "as available at the moment of speaking", or "prepared for some event" ((van der Merwe et al. 1999): 330).

[53] Genesis 1.29

\begin{tabular}{llll}
\hline hinneh & nätattî & läkęm & 'ęt kŏl 'eséę zorea'zęra' \\
Behold & give-1CS-PERF & to you & every plant bearing seed \\
Negotiator & Finite/Predicator & Complement & Complement \\
& Mood Base & Residue & \\
\multicolumn{2}{c}{ (See, I have given you every seed-bearing plant [...]) } & & \\
\hline
\end{tabular}


The two Negotiators hinneh and $n \vec{a}$ may combine to form a single Negotiator with a somewhat different distributional pattern when compared to $n \vec{a}$ alone, as shown in example [2]. Whereas the Negotiator $n \vec{a}$ occurs in volitive clauses after the Finite/ Predicator element, the combined form hinneh-na $\vec{a}$ occurs (like hinneh) in clause-initial position in indicative clauses. The single exception to this is found in Genesis 19.2, where hinneh-na्a appears in a volitive clause.

[2] Samuel 9.6

\begin{tabular}{|c|c|c|c|}
\hline hinneh-nä' & ก̌̌ & $\varnothing$ & bāîr hazo't \\
\hline Behold-please & man of God & (be) & in this city \\
\hline \multirow[t]{2}{*}{ Negotiator } & Subject & Finite/Predicator & circumstantial Adjunct \\
\hline & Mood Base & & Residue \\
\hline
\end{tabular}

Although hinneh is traditionally translated as 'behold', or as 'see' in example [53], it does not have a simple translation into English, and the Negotiator in example [2] is not translated directly. The politeness Negotiator $n \vec{a}$ is used here to soften the speech of a servant to his master, while the hinneh directs the listener's attention to what follows, hence its position at the clause-initial juncture prosody. Di Giulio (di Giulio 2013) contrasts hinneh with 'attâ.

[54] Exodus 10.17

\begin{tabular}{|c|c|c|c|c|c|c|}
\hline$w-$ & 'attâ & $s^{\prime} \bar{a}^{\prime}$ & $n \bar{a}^{\prime}$ & hatțā'tî̀ & 'ak & happa'am \\
\hline And & now & forgive-2MS-IMPV & please & my sin & just & this time \\
\hline \multirow[t]{2}{*}{ Conjunctive Adjunct } & Negotiator & Finite/Predicator & Negotiator & Complement & mood Adjunct & $\begin{array}{l}\text { circumstantial } \\
\text { Adjunct }\end{array}$ \\
\hline & & Mood Base & & Residue & & \\
\hline \multicolumn{7}{|c|}{ (Forgive my offense just this once) } \\
\hline
\end{tabular}

Di Giulio claims that hinneh signals the performance of a declarative speech act, while 'attâ signals the performance of a directive speech act, which correspond respectively to declarative and volitive or interrogative mood in the system established above. In terms of interpersonal interaction, therefore, these two Negotiators can be interpreted as optional markers of mood type. This claim, however, can be disputed, since examples are found which do not seem to correspond to his division (cf. Genesis 12.19 and 2 Chronicles 18.22). The following example may be contrasted with the analysis of example [2] above.

[55] Genesis 4.11

\begin{tabular}{|c|c|c|c|c|c|}
\hline$\overline{w^{e}}$ & 'attâ & 'ärûr & $\varnothing$ & 'āttâ & $\min h \bar{a}^{a} \underline{\text { dāmâ }}$ \\
\hline And & now & cursed & (be) & you & than the ground \\
\hline \multirow[t]{2}{*}{ Conjunctive Adjunct } & Negotiator & Complement & Finite/Predicator & Subject & circumstantial Adjunct \\
\hline & & Residue & Mood base & & Residue \\
\hline
\end{tabular}


Both of these examples display ellipsis of the Finite/Predicator element, and therefore the mood of the clause cannot be understood from Finite/Predicator morphology. Example [2] demonstrates a clear declarative clause, in which the servant states a proposition which can be evaluated as true or false. In [55], however, the clause does not express a declarative, but instead commands a change which would "get the world to match the words" ((Searle 1976): 3).

The particle 'ānn $\hat{a}$ or ' $\bar{a} n n \bar{a}$ ' ('I/we beg you') expresses an urgent request ((van der Merwe et al. 1999): 335). Example [56] exhibits both 'ānnâa and $n \bar{a}$ ', with 'ānnâ in its typical clause-initial position and $n \vec{a}$ in its typical post-Finite/Predicator position.

[56] 2 Kings 20.3

\begin{tabular}{|c|c|c|c|c|}
\hline ānnâ & yhwh & $z^{e} k \underline{k} r$ & $n \bar{a}^{\prime}$ & 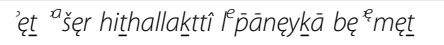 \\
\hline I beg you & God & remember-2MS-IMPV & please & that walk-1CS-PERF before you in truth \\
\hline \multirow[t]{2}{*}{ Negotiator } & Vocative & Finite/Predicator & Negotiator & Complement \\
\hline & & Mood base & & Residue \\
\hline
\end{tabular}

Adjuncts The interpersonal aspect of the clause is realized by two kinds of Adjuncts: circumstantial Adjuncts, which are located in the Residue; and modal Adjuncts, which are part of the Mood base. Modal Adjuncts are of two types: mood Adjuncts and comment Adjuncts. Adjuncts are realized by adverbial groups/particles, prepositional phrases and nominal groups.

Example [34] shows a circumstantial Adjunct of time in thematic position at the beginning of the clause, realized by a prepositional phrase. In example [57] there are two circumstantial Adjuncts of place, the first one realised by an adverbial group and the second by a prepositional phrase. In [58] the temporal circumstantial Adjunct is realised instead by a nominal group.

[57] Deuteronomy 34.5

\begin{tabular}{|c|c|c|c|}
\hline wayyämāt & šām & mošęh 'ębęed yhwh & b'ęręs mô'āb \\
\hline Die-3MS-WYQTL & there & Moses servant of God & in the land of Moab \\
\hline Finite/Predicator & circumstantial Adjunct & Subject & circumstantial Adjunct \\
\hline Mood base & Residue & Mood base & Residue \\
\hline
\end{tabular}

[58] Jeremiah 28.16

\begin{tabular}{lll}
\hline haššānäh & 'attâ & meț \\
This year & you & die-MS-PART \\
Circumstantial Adjunct & Subject & Finite/Predicator \\
Residue & Mood base & \\
(This year you shall die) & & \\
\hline
\end{tabular}


Mood Adjuncts are closely associated with the mood system and its various meanings; in particular, they represent meanings related to modality, temporality and intensity. Examples [6] from the conversation above, and [59] below are mood Adjuncts related to modality. Example [6] expresses possibility, while [59] expresses certainty and [60] expresses even stronger certainty according to van der Merwe et al. (van der Merwe et al. 1999).

[6] 1 Samuel 9.6

\begin{tabular}{|c|c|c|c|}
\hline 'ûlay & yaggî́ & lānû & 'ęt darkenû \\
\hline Perhaps & tell-3MS-IMPF & to us & our way \\
\hline Mood Adjunct & Finite/Predicator & Complement & Complement \\
\hline \multicolumn{2}{|l|}{ Mood base } & \multicolumn{2}{|l|}{ Residue } \\
\hline (perhaps he will & ur errand $[\ldots]$ ) & & \\
\hline
\end{tabular}

[59] Genesis 26.9

\begin{tabular}{lllll}
\hline 'ak & hinneh & ${\text { 'iš }{ }^{e} \underline{k} \underline{a}}$ & $\varnothing$ & $h \hat{\imath}$ \\
Certainly & behold & your wife & (is) & she \\
Mood Adjunct & Negotiator & Complement & Finite/Predicator & Subject \\
Mood Base & & Residue & Mood Base & \\
(Certainly she is your wife!) & & & \\
\hline
\end{tabular}

[60] Exodus 2.14

\begin{tabular}{lll}
\hline 'äken & nôda' & haddābār \\
Certainly & be known-3MS-PERF & the thing \\
Mood Adjunct & Finite/Predicator & Subject \\
Mood base & & \\
(Surely the matter is known) & & \\
\hline
\end{tabular}

Mood Adjuncts related to temporality include those associated with remote or near future or non-future, as well as with positive and negative expectations relative to the time under discussion in the interaction. Examples [61] and [62] express near future and past respectively.

[61] Deuteronomy 32.35

\begin{tabular}{llll}
\hline$k \hat{\imath}$ & qärôb & $\varnothing$ & yôm 'êdām \\
For & soon & (be) & day of their disaster \\
Conjunctive Adjunct & mood Adjunct & Finite/Predicator & Subject \\
& Mood Base & & \\
(for the day of their disaster is soon) & & \\
\hline
\end{tabular}


[62] Deuteronomy 32.17

\begin{tabular}{lll}
\hline$h^{a} \underline{\text { dāšîm }}$ & $\begin{array}{l}\text { miqaārôb } \\
\text { recently } \\
\text { New-MP }\end{array}$ & bäûu \\
Subject & come-3MP-PERF \\
Mood base & & Finite/Predicator \\
(new ones [gods], who came but lately) & & \\
\hline
\end{tabular}

In the following examples, mood Adjuncts of temporality serve to express positive and negative expectations relative to the time under consideration ((Halliday \& Matthiessen 2014): 187). In [64] the negative expectation is expressed by a combination of two mood Adjuncts, the temporal mood Adjunct 'ôd, together with the mood Adjunct of negative polarity $l o^{2}$.

[63] Genesis 29.7

\begin{tabular}{lllll}
\hline hen & 'ôd & hayyôm & $\varnothing$ & gädôl \\
Behold & still & the day & (be) & large \\
Negotiator & mood Adjunct & Subject & Finite/Predicator & Complement \\
& Mood Base & & & Residue \\
(It is still broad daylight) & & & \\
\hline
\end{tabular}

[64] Genesis 17.5

\begin{tabular}{llllll}
\hline$W^{e}-$ & $10^{\prime}$ & yiqqäre' & ôd & 'ęt šimkā & 'ábräm \\
And & NEG & be called-3MS-IMPF & still & your name & Abram \\
Conjunctive Adjunct & mood Adjunct & Finite/Predicator & mood Adjunct & Complement & Subject \\
& Mood base & & & Residue & Mood base \\
\multicolumn{2}{l}{ (and you shall no longer be called Abram) } & & &
\end{tabular}

Comment Adjuncts are outside of the Mood base + Residue structure, and serve as comments on the proposition (propositional) or on the act of exchange (speech-functional) ((Halliday \& Matthiessen 2014): 184). This type of Adjunct is much less common in BH than in English, and attested examples are rather rare.

[65] Joshua 7.20

\begin{tabular}{|c|c|c|c|}
\hline ŏmnâ & 'ānokî̀ & hāțātî̀ & layhwh "lohey yiśrāel \\
\hline Truly & । & sin-1CS-PERF & to the Lord God of Israel \\
\hline \multirow[t]{2}{*}{ Comment Adjunct } & Subject & Finite/Predicator & circumstantial Adjunct \\
\hline & \multicolumn{2}{|c|}{ Mood Base } & Residue \\
\hline
\end{tabular}


[66] Numbers 22.37

\begin{tabular}{|c|c|c|c|c|}
\hline ha- & 'umnām & $10^{\prime}$ & 'ûkal & kabdęęāa \\
\hline INTER & truly & NEG & be able-1CS-IMPF & your honor \\
\hline \multirow[t]{2}{*}{ Negotiator } & comment Adjunct & mood Adjunct & Finite/Predicator & Complement \\
\hline & & Mood Base & & Residue \\
\hline
\end{tabular}

Examples [65] and [66] show the speech-functional comment Adjuncts 'ömnâa (also 'ómnäm) and 'umnäm. The former expresses the speaker's "commitment to the truth of a statement", while the latter is used "to enquire about how a state of affairs correlates with the truth", and thus represents the listener's point of view ((van der Merwe et al. 1999): 310-311).

Complement The Complement is defined as that element which "has the potential of being given the interpersonally elevated status of modal responsibility" even though it does not possess that status ((Halliday \& Matthiessen 2014): 153). Complements are typically realized by nominal groups or prepositional phrases. Examples of the Complement function can be seen in many of the previously-reported example clauses. Examples [43] and [51] both display a Complement marked on the Finite/Predicator element, and therefore realized within the Mood base rather than in the Residue. Example [56] shows a Complement realized by a down-ranked clause. Nominal groups that function as Complement in the role traditionally referred to as the direct object may be marked or unmarked for definiteness. One peculiar feature of $\mathrm{BH}$ is that when nominal groups which function as direct object are marked for definiteness, they are normally preceded by the definite object marker particle 'et, while nominal groups that are unmarked for definiteness also lack marking for object status.

[67] Deuteronomy 24.18

\begin{tabular}{|c|c|c|c|c|c|}
\hline ken & 'ànokî̀ & $m^{e}$ șaw ${ }^{e} \underline{a}$ & $1 a^{a} \dot{s} \hat{o} \underline{t}$ & 'ęt & haddāboär hazzę \\
\hline Thus & । & command-MS-PART & do-INF.CONS & OBJ & this thing \\
\hline \multirow[t]{2}{*}{ Conjunctive Adjunct } & Subject & Finite/Predicator $[\subset]$ & Predicator & \multicolumn{2}{|c|}{ Complement } \\
\hline & \multicolumn{2}{|c|}{ Mood Base } & & \multicolumn{2}{|c|}{ Residue } \\
\hline
\end{tabular}

[68] Genesis 19.8

\begin{tabular}{|c|c|c|c|c|}
\hline raq & lāanāšìm hāel & 'al & $t^{a} a^{a} \dot{s} \hat{u}$ & dāābār \\
\hline Only & to these men & NEG & do-2MP-IMPF & thing \\
\hline \multirow[t]{2}{*}{ Conjunctive Adjunct } & circumstantial Adjunct & mood Adjunct & Finite/Predicator & Complement \\
\hline & Residue & Mood Base & & Residue \\
\hline
\end{tabular}




\section{Polarity}

In the system of POLARITY, the primary opposition is between 'positive' and 'negative'. The former is the unmarked option, while the latter is marked. The specific marker for negative polarity varies depending on mood type and other factors. The following examples illustrate the negative markers and their uses.

Indicative clauses are normally marked for negative polarity by means of the mood Adjunct $l 0^{\circ}$, as in example [66] and others above, as well as in [69] below. When negating the clause, the mood Adjunct is located directly before the Finite/Predicator. The negative mood Adjuncts $b a l$ and $b^{e} l \hat{\imath}$ are also used for the expression of negative polarity in indicative clauses, especially in poetry, as in [70] and [71] below.

[69] Exodus 14.28

\begin{tabular}{llll}
\hline $10^{\prime}$ & niš'ar & bāhęm & 'ad 'ęhad \\
NEG & remain-3MS-PERF & in it & until one \\
Mood Adjunct & Finite/Predicator & circumstantial Adjunct & circumstantial Adjunct \\
Mood Base & Residue & \\
(not one of them remained in it) & & \\
\hline
\end{tabular}

[70] Proverbs 22.29

\begin{tabular}{lll}
\hline bal & yityașse & lip̄nê ha šukîm \\
NEG & stand-3MS-IMPF & before unimportant-MS \\
Mood Adjunct & Finite/Predicator & circumstantial Adjunct \\
Mood Base & Residue \\
(He shall not stand before unimportant men) & \\
\hline
\end{tabular}

[71] Psalms 19.4

\begin{tabular}{lll}
\hline$b^{e} / \hat{\imath}$ & nišmä & qôlām \\
NEG & be heard-MS-PART & their voice \\
Mood Adjunct & Finite/Predicator & Subject \\
Mood base & & \\
(their voice is not heard) & & \\
\hline
\end{tabular}

Volitive clauses are typically negated with the negative mood Adjunct 'al, which is used with the jussive and cohortative forms in the third and first persons respectively. The imperative form of the verb, however, is not used in imperative clauses with negative polarity. Instead, one of two forms may be used, depending on the nature of the command. The mood Adjunct 'al is used with the second-person jussive form (usually formally indistinguishable from the imperfect) if the command refers to a specific situation; $l o^{\prime}$ is used with the second-person imperfect form if the command refers to a general prohibition. 
[72] 1 Samuel 16.7

\begin{tabular}{lll}
\hline 'al & tabeț & 'él mar'ehû \\
NEG & look-2MS-JUS & to his appearance \\
mood Adjunct & Finite/Predicator & Complement \\
Mood base & & Residue \\
(Do not look at his appearance) & & \\
\hline
\end{tabular}

[73] Exodus 20.13

\begin{tabular}{ll}
\hline $10^{\prime}$ & tirșāh \\
NEG & murder-2MS-IMPF \\
mood Adjunct & Finite/Predicator \\
Mood base & \\
(You shall not murder) & \\
\hline
\end{tabular}

The use of the negative existence particle 'ên is described in Finite/Predicator above.

\section{Modality}

The intermediate degrees of meaning between the positive and negative poles of the system of POLARITY are referred to as MODALITY. The modality related to propositions is called modalization, and it expresses degrees of probability and degrees of usuality; that related to proposals instead is referred to as modulation, which expresses degrees of obligation in commands and degrees of inclination in offers ((Halliday \& Matthiessen 2014): 177-178). The systems associated with modality are not as fully developed in $\mathrm{BH}$ as they are in English. While this may be due to a smaller variety of forms in $\mathrm{BH}$ with respect to modern English, it is more likely due to the fact that the $\mathrm{BH}$ is a dead language known from a rather limited corpus of texts, which do not represent the complete variety of texts and contexts present in the lives of the users of the language when it was a living tongue.

Degrees of probability were discussed above in the section on mood Adjuncts, where examples [6], [57] and [58] showed the use of the three Adjuncts 'ûlay (perhaps), 'ak (certainly) and 'âken (certainly). Van der Merwe et al. (van der Merwe et al. 1999) describe these as lying on a cline from strong certainty ('âken) to certainty ('ak k) to possibility ('ûlay). Gianto (Gianto 1998), on the other hand, includes 'ûlay and 'ak, but not 'āken among the particles which express epistemic modality. Waltke and O'Connor (Waltke \& O'Connor 1990) claim that both 'ak and 'äken highlight a conclusion which is in contrast to what had been previously assumed.

Unlike English, BH does not possess a rich set of auxiliary verbs to express degrees of probability; however, Gianto (Gianto 1998) points out that the imperfect form of the verb may express various degrees of certainty, as represented by the four subtypes of epistemic modality he distinguishes (from more to less certain): declarative, assertive, assumptive and dubitative. These subtypes of epistemic modality correspond to the degrees of probability in the SFG notion of modalization. However, since they are all realized by means of the same form, they are therefore not grammaticalized on the 
lexicogrammatical stratum in BH. Furthermore, Gianto also notes that these same degrees of probability may be realized in other cases by clauses with imperative, jussive and perfect verb forms. Nevertheless, it was shown in Finite/Predicator above that certainty can be realized in the verbal group complex by means of the infinitive absolute, as in example [42a].

Gianto (ibid.: 190-191) furthermore discusses three subtypes of deontic modality, which generally corresponds to the notion of modulation in SFG: obligative, permissive and abilitative. Obligative and permissive modality equate to the modulation type obligation on commands, whereas abilitative modality is related to the modulation type inclination, although Halliday and Matthiessen (Halliday \& Matthiessen 2014) note that the category of ability/potentiality is "on the fringe of the modality system" in English. It is significant that Halliday and Matthiessen (ibid.) relate ability/potentiality directly to the category of inclination, and classify "can/is able to as 'low'-value variants of will/ is willing to", since $\mathrm{BH}$ has only two auxiliary verbs which express modality, and those are yākol (can, be able to) and 'ābāh (be willing), which may be seen above in examples (Sinclair 1999) and Steiner 1997. Much more work needs to be done to establish a systemic functional account of modality in Biblical Hebrew.

\section{Conclusions}

The present study represents only a preliminary attempt to describe the interpersonal resources of the Biblical Hebrew clause, and much work remains to be done in order to achieve a more complete and accurate description of these resources, much less a description of the lexicogrammatical resources associated with the other metafunctions or an adequate systemic representation of the lexicogrammar of Biblical Hebrew. The purpose of this study was to describe the interpersonal resources of the Biblical Hebrew clause, in order to elucidate the salient characteristics of the clause as an element in an interpersonal exchange. Starting from Halliday and Matthiessen's (Halliday \& Matthiessen 2014) account of the English MOOD system, the SFG accounts of Bandstra (Bandstra 2008) and Tatu (Tatu 2008) were critically evaluated and rejected as models for the description of $\mathrm{BH}$, although certain aspects of their descriptions are useful and correct. In particular, their accounts seem to lean too heavily on descriptions of English and mostly leave the language's systemic potential undescribed.

The present account of the MOOD system in Biblical Hebrew began with a description of the typical realizations of the SPEECH FUNCTION system in the lexicogrammatical system of MOOD TYPE. The system of MOOD TYPE and the grammatical means by which it is realized were then explored. It was shown that $\mathrm{BH}$ relies principally on Finite/Predicator morphology for the realization of distinctions between indicative and volitive clauses, and between the three types of volitive; however, within the category of indicative clauses, distinctions between declarative and interrogative, as well as between the different types of interrogative, are realized by means of Negotiators and interrogative pro-forms. The beginning of the clause was identified as the location where interpersonal meanings are realized by the Finite/Predicator and/or Negotiator, which are the most salient elements in the enactment of interpersonal meanings in the negotiation of exchange, and in particular in the realization of the choices available in the system of MOOD TYPE. The fused Finite/Predicator element - typically realizing an implicit Subject - was established as the central element around which 
interpersonal meanings are realized. The elements which encode mood in the clause were then each described, followed by a brief account of POLARITY and MODALITY.

Although there is a long tradition of exegetical interpretation of the text of the Hebrew Bible, as well as of the grammatical characteristics of its language, and much recent work has been done in the application of modern linguistic methods to the grammar of Biblical Hebrew, there is still much to be done from a systemic functional perspective. As regards the system of MOOD and the interpersonal meanings associated with it, the present study is only a tentative outline. Deeper and more systematic research needs to be carried out involving the analysis of the available corpus of texts, in particular so that adequate accounts of modality and the various types of Adjuncts and Negotiators might be developed. Finally, a more complete system network for the systems associated with Biblical Hebrew MOOD remains to be developed.

\title{
Endnotes
}

${ }^{1}$ Two further exceptions to this tendency are Garnowski (Garnowski 1999) and Payne (Payne 1990). The author of the present study was unable to consult these theses at the time of writing.

${ }^{2}$ The present study follows the conventions used in the systemic functional literature. Terms in all caps (MOOD) refer to the names of systems, while an initial majuscule (Subject) is used for the name of a structural function.

${ }^{3}$ The English version cited throughout the present study is the New Jewish Publication Society (NJPS, 1985) translation. The text has been edited in order to remove narrative elements surrounding the quoted dialogues, to shorten the dialogues or individual turns by eliminating, for example, bound clauses not relevant to the analysis, and finally to change idiomatic English translations where they obscure the grammatical point under discussion. The transliteration system used for the examples is the Brill Scholarly transliteration of biblical Hebrew, version 0.4, 9 July 2015, by Pim Rietbroek.

\author{
Abbreviations \\ WYQTL: wayyiqtol verb form \\ Acknowledgements \\ Not applicable. \\ Funding \\ Not applicable. \\ Availability of data and materials \\ Not applicable. \\ Authors' contributions \\ Not applicable. \\ Competing interests \\ The author declares that he has no competing interests. \\ Consent for publication \\ Not applicable.
}

1CP: First-person common gender plural; 1CS: First-person common gender singular; 2MP: Second-person masculine plural; 2MS: Second-person masculine singular; 3FS: Third-person feminine singular; 3MP: Third-person masculine plural; 3MS: Third-person masculine singular; BH: Biblical Hebrew; COH: Cohortative; EMPH: Emphatic marker; EXST: Existential particle; EXST.NEG: Negative existential particle; IMPF: Imperfect; IMPV: Imperative; INF.ABS: Infinitive absolute; INF.CONS: Infinitive construct; INTER: Interrogative; JUS: Jussive; MP: Masculine plural; MS: Masculine singular; NEG: Negative; OBJ: Definite direct object marker; PART: Participle; PERF: Perfect; WQTL: wegatal verb form; 
Ethics approval and consent to participate

Not applicable.

\section{Publisher's Note}

Springer Nature remains neutral with regard to jurisdictional claims in published maps and institutional affiliations.

Received: 10 March 2017 Accepted: 18 April 2017

Published online: 18 May 2017

\section{References}

Andersen, T. David. 1986. Problems in analysing Hebrew poetry. East Asia Journal of Theology 4(2): 68-94.

Anstey, Matthew P. 2009. The Biblical Hebrew qatal verb: a functional discourse grammar analysis. Linguistics 47(4): $825-844$.

Bandstra, Barry. 2008. Genesis 1-11: a Handbook on the Hebrew Text. Waco: Baylor University Press.

Bardi, Mohamed Ali. 2008. A systemic functional description of the grammar of Arabic. PhD dissertation. Sydney: Macquarie University.

Blau, Joshua. 1993. A grammar of biblical Hebrew, 2nd ed. Wiesbaden: Harrassowitz Verlag.

Brettler, Marc Zvi. 2010. The "coherence" of ancient texts. In Gazing on the deep: ancient near eastern and other studies in honor of tzvi abusch, ed. J. Stackert, B.N. Porter, and D.P. Wright, 411-419. Bethesda, Maryland: CDL Press.

Caffarel, Alice. 2006. A systemic functional grammar of French: from grammar to discourse. London: Continuum.

Caffarel, A., J.R. Martin, and C.M.I.M. Matthiessen (eds.). 2004. Language typology: a functional perspective. Amsterdam and Philadelphia: John Benjamins.

Christiansen, Bent. 2009. A linguistic analysis of the Biblical Hebrew particle nā’: A test case. Vetus Testamentum 59: 379-393.

Chrzanowski, Jarosław. 2013. Auxiliaries: biblical Hebrew. In Encyclopedia of Hebrew language and linguistics, volume 1 , ed. Geoffrey Khan, 244-249. Leiden and Boston: Brill.

di Giulio, Marco. 2013. Discourse Marker: Biblical Hebrew. In Encyclopedia of Hebrew language and linguistics, volume 1, ed. Geoffrey Khan, 757-758. Leiden and Boston: Brill.

Edzard, Lutz. 2011. Biblical Hebrew. In The Semitic languages: an international handbook, ed. Stefan Weninger, 480514. Berlin and Boston: Walter de Gruyter.

Fassberg, Steven E. 1999. The lengthened imperative קטָלָ in Biblical Hebrew. Hebrew Studies 40: 7-13.

Floor, Sebastian J. 2004. From Information Structure, Topic and Focus, to Theme in Biblical Hebrew Narrative. PhD. Thesis. Stellenbosch: University of Stellenbosch.

Garnowski, Alice. 1999. A study in the development of a systemic functional grammar for biblical Hebrew clauses: a preliminary demonstration of systemic functional Grammar's explanatory power in clause level structure and meaning. M.Phil thesis. Birmingham: University of Birmingham.

Gesenius, Wilhelm and Kautzsch, E. 2006 [1909]. Gesenius' Hebrew Grammar. Mineola: Dover

Gianto, Agustinus. 1998. Mood and modality in classical Hebrew. Israel Oriental Studies 18: 183-198.

Halliday, Michael A.K. 1995. Fuzzy grammatics: a systemic functional approach to fuzziness in natural language. In Fuzzy Systems, 1995, International Joint Conference of the Fourth IEEE International Conference on Fuzzy Systems and The Second International Fuzzy Engineering Symposium., Proceedings of 1995 IEEE Int, Volume 1, 9-26. IEEE

Halliday, M.A.K., and C.M.I.M. Matthiessen. 1999. Construing experience through meaning: a language-based approach to cognition. London and New York: Continuum.

Halliday, M.A.K., and C.M.I.M. Matthiessen. 2014. Halliday's introduction to functional grammar, 4th ed. London and New York: Routledge.

Joüon, Paul, and Takamitsu Muraoka. 1996. A grammar of biblical Hebrew. Rome: Editrice Pontificio Istituto Biblico. Levinsohn, Stephen H. 1990. Unmarked and marked instances of topicalization in Hebrew. Work Papers of the 1990 Summer Institute of Linguistics, University of North Dakota Session, Volume 34: 21-33.

Li, Tarsee. 2006. Va'yehi as discourse marker in Kings. Andrews University Seminary Studies 44(2): 221-239.

Lipiński, Edward. 1997. Semitic languages: outline of a comparative grammar. Leuven: Peeters.

Madasu, Joel. 2015. An Analysis of the Process Types and the Syntactic Role of the Existential Particle yesh (שי (י) in Biblical Hebrew: A Traditional-Systemic Functional Approach. PhD Dissertation. Winston-Salem, North Carolina: Piedmont International University

Matthiessen, Christian M.I.M. 2004. Descriptive motifs and generalizations. In Language Typology: A functional perspective, ed. Caffarel Alice, J.R. Martin, and C.M.I.M. Matthiessen, 537-673. Amsterdam and Philadelphia: John Benjamins.

Matthiessen, Christian M.I.M. 2007. Lexicogrammar in systemic functional linguistics: descriptive and theoretical developments in the 'IFG' tradition since the 1970s. In Continuing discourse on language: a functional perspective, volume 2, ed. Ruqaiya Hasan, Christian Matthiessen, and Jonathan Webster, 765-858. London: Equinox.

Matthiessen, Christian M.I.M. and Kasper Robert. 1987. Representational Issues in Systemic Functional Grammar and Systemic Grammar and Functional Unification Grammar. Reprinted from the Proceedings of the 12th International Systemic Workshop in Ann Arbor, MI., August 21-24, 1985. Marina del Rey, CA: Information Sciences Institute.

Meister, Mauro Fernando. 1996. Interrogatives in Biblical Hebrew: A Case Study in the Joseph Narrative. PhD Dissertation. University of Stellenbosch

Moshavi, Adina. 2010. Word order in the biblical Hebrew finite clause: a syntactic and pragmatic analysis of preposing. Winona Lake: Eisenbrauns.

Payne, Geoffrey. 1990. Discourse Analysis of Biblical Hebrew Texts. PhD Dissertation. Edinburgh: University of Edinburgh.

Polak, Frank. 2006. Sociolinguistics: a key to the typology and the social background of Biblical Hebrew. Hebrew Studies 47: 115-162.

Rendsburg, Gary A. 2003. A comprehensive guide to israelian Hebrew: grammar and lexicon. Orient 38: 5-35. 
Sáenz-Badillos, Angel. 1993. A History of the Hebrew Language. Cambridge: Cambridge University Press.

Searle, John R. 1976. A classification of illocutionary acts. Language in Society 5(1): 1-23.

Sinclair, Cameron. 1999. Are nominal clauses a distinct clausal type? In The verbless clause in biblical Hebrew: linguistic approaches, ed. Cynthia Miller, 51-75. Winona Lake: Eisenbrauns.

Sperber, Alexander. 1943. Hebrew grammar: A new approach. Journal of Biblical Literature 62(3): 137-242.

Steiner, Richard C. 1997. Ancient Hebrew. In The Semitic languages, ed. Robert Hetzron, 145-173. London and New York: Routledge.

Tatu, Silviu. 2008. The Qatal//Yiqtol (Yiqtol//Qatal) verbal sequence in semitic couplets: a case study in systemic functional grammar with applications on the hebrew psalter and ugaritic poetry. Piscataway: Gorgias.

Teruya, Kazuhiro. 2004. Metafunctional profile of the grammar of Japanese. In Language Typology: A functional perspective, ed. Caffarel Alice, J.R. Martin, and C.M.I.M. Matthiessen, 185-254. Amsterdam and Philadelphia: John Benjamins.

Teruya, K., E. Akerejola, T.H. Andersen, A. Caffarel, J. Lavid, C.M.I.M. Matthiessen, U.H. Petersen, P. Patpong, and F. Smedegaard. 2007. Typology of MOOD: a text-based and system-based functional view. In Continuing discourse on language: a functional perspective, volume 2, ed. Ruqaiya Hasan, Christian Matthiessen, and Jonathan Webster, 859-920. London: Equinox.

Thai, Minh Duc. 2004. Metafunctional profile of the grammar of Vietnamese. In Language Typology: A functional perspective, ed. Caffarel Alice, J.R. Martin, and C.M.I.M. Matthiessen, 397-432. Amsterdam and Philadelphia: John Benjamins.

Toffelmire, Colin M. 2014. Orienting the event: register and the Day of YHWH in the prophetic book of Joel. PhD dissertation. Hamilton, Ontario: McMaster Divinity College.

van de Mieroop, Marc. 2007. A History of the Ancient Near East: ca. 3000-323 BC, 2nd ed. Oxford: Blackwell.

van der Merwe, Christo H.J. 2003. Some recent trends in Biblical Hebrew linguistics: a few pointers towards a more comprehensive model of language use. Hebrew Studies 44: 7-24.

van der Merwe, Christo H.J., Jackie A. Naudé, and Jan H. Kroeze. 1999. A biblical Hebrew reference grammar. Sheffield: Sheffield Academic Press.

Waltke, B.K., and M. O'Connor. 1990. An introduction to biblical Hebrew syntax. Winona Lake: Eisenbrauns.

Submit your manuscript to a SpringerOpen ${ }^{\circ}$ journal and benefit from:

- Convenient online submission

- Rigorous peer review

- Immediate publication on acceptance

- Open access: articles freely available online

- High visibility within the field

- Retaining the copyright to your article

Submit your next manuscript at $>$ springeropen.com 